\title{
FEDERAL RESERVE BANK OF SAN FRANCISCO \\ WORKING PAPER SERIES
}

\section{Betting the House}

\author{
Òscar Jordá \\ Federal Reserve Bank of San Francisco \\ and University of California Davis \\ Moritz Schularick \\ University of Bonn and CEPR \\ Alan M. Taylor \\ University of California Davis, \\ NBER and CEPR
}

December 2014

Working Paper 2014-28

http://www.frbsf.org/economic-research/publications/working-papers/wp2014-28.pdf

The views in this paper are solely the responsibility of the authors and should not be interpreted as reflecting the views of the Federal Reserve Bank of San Francisco or the Board of Governors of the Federal Reserve System. 


\title{
Betting the House*
}

\section{Òscar Jordà ${ }^{\dagger} \quad$ Moritz Schularick Alan M. Taylor $^{\S}$}

\author{
December 2014
}

\begin{abstract}
Is there a link between loose monetary conditions, credit growth, house price booms, and financial instability? This paper analyzes the role of interest rates and credit in driving house price booms and busts with data spanning 140 years of modern economic history in the advanced economies. We exploit the implications of the macroeconomic policy trilemma to identify exogenous variation in monetary conditions: countries with fixed exchange regimes often see fluctuations in short-term interest rates unrelated to home economic conditions. We use novel instrumental variable local projection methods to demonstrate that loose monetary conditions lead to booms in real estate lending and house prices bubbles; these, in turn, materially heighten the risk of financial crises. Both effects have become stronger in the postwar era.
\end{abstract}

Keywords: financial crises, monetary policy, leverage, credit, house prices, local projections, instrumental variables

JEL Codes: C14, $\mathrm{C}_{38}, \mathrm{E}_{32}, \mathrm{E}_{37}, \mathrm{E}_{42}, \mathrm{E}_{44}, \mathrm{E}_{51}, \mathrm{E}_{52}, \mathrm{~F}_{41}, \mathrm{Go1}, \mathrm{G} 21, \mathrm{~N} 10, \mathrm{~N}_{20}$

\footnotetext{
*The views expressed herein are solely the responsibility of the authors and should not be interpreted as reflecting the views of the Federal Reserve Bank of San Francisco or the Board of Governors of the Federal Reserve System. This work is part of a larger project kindly supported by a research grant from the Institute for New Economic Thinking (INET) administered by UC Davis. Schularick thanks the Volkswagen Foundation for generous financial support. We are indebted to Katharina Knoll who permitted us to use her cross-country database of historical housing prices. We thank participants in the International Seminar on Macroeconomics in Riga, Latvia for useful comments and suggestions. We are particularly grateful to Early Elias, Helen Irvin and Niklas Flamang for outstanding research assistance. All errors are ours.

${ }^{\dagger}$ Federal Reserve Bank of San Francisco; and Department of Economics, University of California, Davis (oscar.jorda@sf.frb.org; ojorda@ucdavis.edu).

‡Department of Economics, University of Bonn; and CEPR (moritz.schularick@uni-bonn.de).

$\S$ Department of Economics and Graduate School of Management, University of California, Davis; NBER; and CEPR (amtaylor@ucdavis.edu).
} 
How do monetary and credit conditions affect housing booms and busts? Do low interest rates cause households to lever up on mortgages and bid up house prices, thus increasing the risk of financial crisis? And what, if anything, should central banks do about it? Can policy directed at housing and credit conditions, with monetary or macroprudential tools, lead a central bank astray and dangerously deflect it from single- or dual-mandate goals? Such questions suffuse the debate on the causes of and responses to the global financial crisis.

Yet while the crisis has passed, finding the answers to these questions still looms large in the policy challenges facing policymakers and, especially, central banks. In an effort to de-froth the housing market, the Swedish Riksbank opted for tighter monetary policy. The Bank of England pondered when to raise rates from current record-low levels against the backdrop of a booming housing market, especially in London and the South East, where surges in prices and mortgage lending had in part been fueled by the government's Help to Buy scheme. Meanwhile the Norges Bank earned a reprieve by using new macroprudential tools to cool off a housing boom without cratering the economy. Canada and Australia survived the 2008 crisis largely unscathed, but so did their housing booms.

Central banks face difficult challenges as they try to address multiple goals with few instruments, as shown by current and past collisions between inflation-output targets and housing bubble concerns. This paper provides greater empirical detail from the front lines of these policy conflicts which may guide the new monetary and macro prudential policy regimes being designed after the recent crisis.

In this current environment, to say that the recent crisis and its aftermath has led to a reassessment of the importance of housing finance for the macroeconomy would be a distinct understatement. Dissecting the sources of house price fluctuations and their effect on household spending, residential investment, the health of financial intermediaries, and ultimately on real economic outcomes, has become a top research priority. In addition to Mian and Sufi's (2014) influential book, a rapidly growing literature investigates the nexus between monetary policy and house prices as well as the implications of house price fluctuations for monetary policy (Del Negro and Otrok 2007; Goodhart and Hofmann 2008; Jarocinski and Smets 2008; Allen and Rogoff 2011; Glaeser, Gottlieb and Gyourko 2010; Williams 2011; Kuttner 2012; Adam and Woodford 2013). The link between monetary conditions, mortgage borrowing, and house price appreciation has attracted considerable attention in some quarters (e.g., Leamer 2007; J. Taylor 2007; Bernanke 2010). Many have wondered whether the low interest rate environment that prevailed in the years before the 2008 crisis contributed to the house price booms experienced in many Western economies before the recent crash. 
House price data are easily available from institutions such as the OECD or the Federal Reserve Bank of Dallas for about 20 advanced economies starting in the mid-1970s, but are much more scattered for earlier times. The same can be said of mortgage credit data. As a result, previous research has, with few exceptions such as Bordo and Landon-Lane (2013) or Reinhart and Reinhart (2011), focused on the decades of the so-called Great Moderation. But such a limited sample, focused on an historically atypical era of peculiar macroeconomic and financial tranquility, calls into question the robustness of the research and the conclusions currently being used as a guide to policy. Housing booms and busts, just like financial crises, are rare events. In order to gain statistical power one needs much longer samples, but these data are very difficult to obtain. Our work fills this void.

This paper analyzes the link between monetary conditions, credit growth, and house prices using data spanning 140 years of modern economic history across 14 advanced economies. Such a long and broad historical analysis has become possible by compiling two datasets, both the result of an extensive multi-year data collection effort. The first dataset covers disaggregated bank credit data, including real estate lending to households and non-financial businesses for 17 countries (Jordà, Schularick, and Taylor 2014). The second dataset, compiled for a study by Knoll, Schularick and Steger (2014), presents newly unearthed data covering long-run house prices for 14 out of the 17 economies in the first dataset, from 1870 to 2012. This is the first time both datasets have been combined.

We make three core contributions. First, we discuss long-run trends in mortgage lending, home ownership, and house prices and show that the 2oth century has indeed been an era of increasing "bets on the house." The strong rise in aggregate private debt over GDP that can be observed in many Western economies in the second half of the 2oth century has been mainly driven by a sharp increase in mortgage debt. Mortgage credit has risen dramatically as a share of banks' balance sheets from about one third at the beginning of the 2oth century to about two thirds today. As a result, the intermediation of savings into the mortgage market has become the primary business of banking, eclipsing the stylized textbook view of banks financing the capital formation of businesses.

Second, turning to the cyclical fluctuations of lending and house prices we use novel instrumental variable local projection methods to show that throughout history loose monetary conditions were closely associated with an upsurge in real estate lending and house prices. House prices, interest rates, and credit aggregates may be jointly determined in equilibrium, and this makes establishing causality difficult. Pairing local projections with instrumental variable methods allow us to tease out this causal effect, where we exploit the implications of the well-known policy trilemma in international macroeconomics (Obstfeld and Taylor 2004). Broadly speaking, when countries peg to some base currency they effectively import the base economy's monetary policy, even if it 
is at odds with home economic conditions. Exchange rate pegs therefore provide a source of exogenous variation in monetary conditions. By conditioning on a rich set of domestic macroeconomic controls, we are able to isolate exogenous fluctuations in the short-term interest rate imported via the peg and trace the effect of these fluctuations over time on other variables.

Third, we also expose a close link between mortgage credit and house price booms on the one hand, and financial crises on the other. Over the past 140 years of modern macroeconomic history, mortgage booms and house price bubbles have been closely associated with a higher likelihood of a financial crisis. This association is more noticeable in the post-WW2 era, which was marked by the democratization of leverage through housing finance.

These findings have important implications for the debate about central bank policy in the aftermath of the crisis: how should policy makers think about the financial stability risks that stem from extended periods of ultra-low interest rates? How should they be weighed against the objective of restoring full employment? The long-run historical evidence uncovered in this study clearly suggests that central banks have reasons to worry about the side-effects of loose monetary conditions. During the 2oth century, real estate lending became the dominant business model of banks. As a result, the effects that low interest rates have on mortgage borrowing, house prices and ultimately financial instability risks have become considerably stronger.

While these historical insights suggest that the potentially destabilizing byproducts of easy money must be taken seriously, it is by no means an obvious conclusion that tighter monetary conditions are always the right answer. From a policy perspective, the most relevant implication of our study is that central banks must be mindful of these side-effects and address them, possibly through the greater use of macro-prudential tools. Macroeconomic stabilization policy has implications for financial stability, and vice versa. The idea that these two objectives can or should be looked at in isolation is not borne out by modern macroeconomic history.

\section{Old Questions, NEW DATA}

As discussed in the introduction, this study combines two newly assembled historical datasets. The first dataset covers long-run disaggregated bank credit data for 17 advanced economies since 1870 . It tracks the share of mortgage lending in total bank lending for most countries back to the 19th century (Jordà, Schularick, and Taylor 2014). Moreover, for a cross-section of countries, it makes possible to back out the share of bank credit to businesses and to households. The underlying data come from a broad range of sources, 
Table 1: Data sources, period, and coverage details of the credit and house price data series

For each country, we show the period covered by the mortgage lending data, the period covered by the house price index, and the method of index construction.

\begin{tabular}{lccl}
\hline \hline Country & Mortgage lending & House prices & Type of house price index \\
\hline Australia & $1870-2011$ & $1870-2012$ & Median price; partly mix-adjusted \\
Belgium & $1885-2011$ & $1878-2012$ & Median price; partly mix-adj. \\
Canada & $1874-2010$ & $1921-2012$ & Avg. prices \\
Switzerland & $1870-2011$ & $1900-2012$ & Avg. prices; partly mix-adj. \\
Germany & $1883-2011$ & $1870-2012$ & Avg. prices; partly mix-adj. \\
Denmark & $1875^{-2010}$ & $1875^{-2012}$ & Avg. prices; SPAR \\
Spain & $1904-2012$ & $1970-2012$ & OECD after 1970 only \\
Finland & $1927-2011$ & $1905-2012$ & Av. sq. m. price; partly mix-adj. hedonic \\
France & $1870-2010$ & $1870-2012$ & Repeat sales; partly mix-adj. hedonic \\
U.K. & $1880-2011$ & $1899-2012$ & Avg. prices; partly mix-adj. \\
Italy & $1870-2012$ & $1970-2012$ & OECD after 1970 only \\
Japan & $1893-2011$ & $1913-2012$ & Avg. prices; partly mix-adj. \\
Netherlands & $1900-2011$ & $1870-2012$ & Repeat sales; partly SPAR \\
Norway & $1870-2010$ & $1870-2012$ & Repeat sales; hedonic \\
Portugal & $1920-2012$ & - & No data \\
Sweden & $1871-2011$ & $1870-2012$ & mix-adj; SPAR \\
U.S. & $1896-2011$ & $1890-2012$ & Repeat sales; partly mix-adj. \\
\hline \hline
\end{tabular}

Notes: For mortgage lending, the financial institutions covered include commercial banks (CB) and other financial institutions (OFI) such as savings banks, credit unions, and building societies. Data generally cover all monetary financial institutions. The following exceptions apply. Australia: pre-WW2 mortgage loans are from savings banks only; Belgium: pre-WW2 mortgage loans are OFIs only; Canada: mortgage loans before 1954 are OFIs only; Germany: pre-1920 mortgage loans are OFIs only; Denmark: pre-WW2 mortgage loans are OFIs only; Japan: pre-WW2 mortgage loans are CBs only; Norway: pre-1900 mortgage loans are mortgage banks only; USA: pre-1896 real estate loans are savings banks only.

Sources: Jordà, Schularick, and Taylor (2014) and Knoll (2014).

including economic and financial history studies, journal articles, yearbooks of statistical offices and central banks, as well as sources from central and private bank archives. For some countries, the dataset incorporates existing series from economic historians or statistical offices.

We combine these historical credit data with a novel dataset covering long-run house prices for 14 advanced economies from the 19th century until today (Knoll, Schularick, and Steger 2014). This newly assembled source represents the first major attempt to construct long-run house price indices for the advanced economies. Relative to previous studies of long-run trends in house prices, such as Bordo and Landon Lane (2013), it approximately doubles the number of country-year observations. The dataset reaches back to the 1870 in the case of Australia, Belgium, Denmark, France, the Netherlands, 
Norway, and Sweden. Data for the U.S. and the U.K. start in the 189os and from the early 1900 in the case of Finland, Germany, Switzerland, and Japan. Data for Canada start in the early 1920s. Compared to previous studies, house price series for the U.K., Japan, and Switzerland are extended by more than 30 years and for more than 40 years in the case of Belgium. Relying on more than 6o different sources, the data combine existing indices with new series constructed on the basis of published and unpublished materials.

Table 1 summarizes the coverage of the credit and house price data as well as the principal type of the house price index used. Some caveats are worth discussing. The construction of historical house price indices entails a number of specific challenges. The house is a bundle of the structure and the land used in its construction. An ideal index would capture the appreciation of the price of a standard, unchanging house which is hard to identify. This makes the construction of house price indices complex and various methods have been proposed. As a result, the reconstruction of historical house price data requires a number of concessions between the ideal and the possible. The historical data vary across countries and time, with respect to the method used for index construction, and the within-country geographic coverage and the type of dwellings. Some series are calculated on the basis of list or transaction prices while others rely on appraisal values. All of these issues may pose a challenge to comparability. However, at present, these data represent the best possible and most comprehensive basis for an analysis of house prices in the long run.

\section{TRENDS IN HOUSING FINANCE, HOME OWNERSHIP, AND HOUSE PRICES: 1870-2012}

Over the last 140 years, the business of banking has gradually evolved from business loans to mortgages. Figure 1 displays the path of mortgage and non-mortgage lending (mostly unsecured lending to businesses) relative to GDP from 1870 to the present for the sample of 17 economies for which we have data (a slightly larger sample than is available for house prices). It is immediately evident from the graph that mortgage borrowing has accelerated markedly in almost all advanced economies after WW2. At the beginning of the 2oth century, mortgage credit stood at about $20 \%$ of GDP on average. By 2010, average mortgage credit approached $70 \%$ of GDP. Banks and households in the Western world have been betting the house. This is true even in countries such as Switzerland and Germany where there has been much less political emphasis and subsidization of home ownership.

Figure 2 presents the data disaggregated by country. The figure shows that for most countries, mortgage lending now accounts for the larger part of bank lending. A 
Figure 1: Bank mortgage and non-mortgage lending to GDP, 1870-2011, average for 17 countries

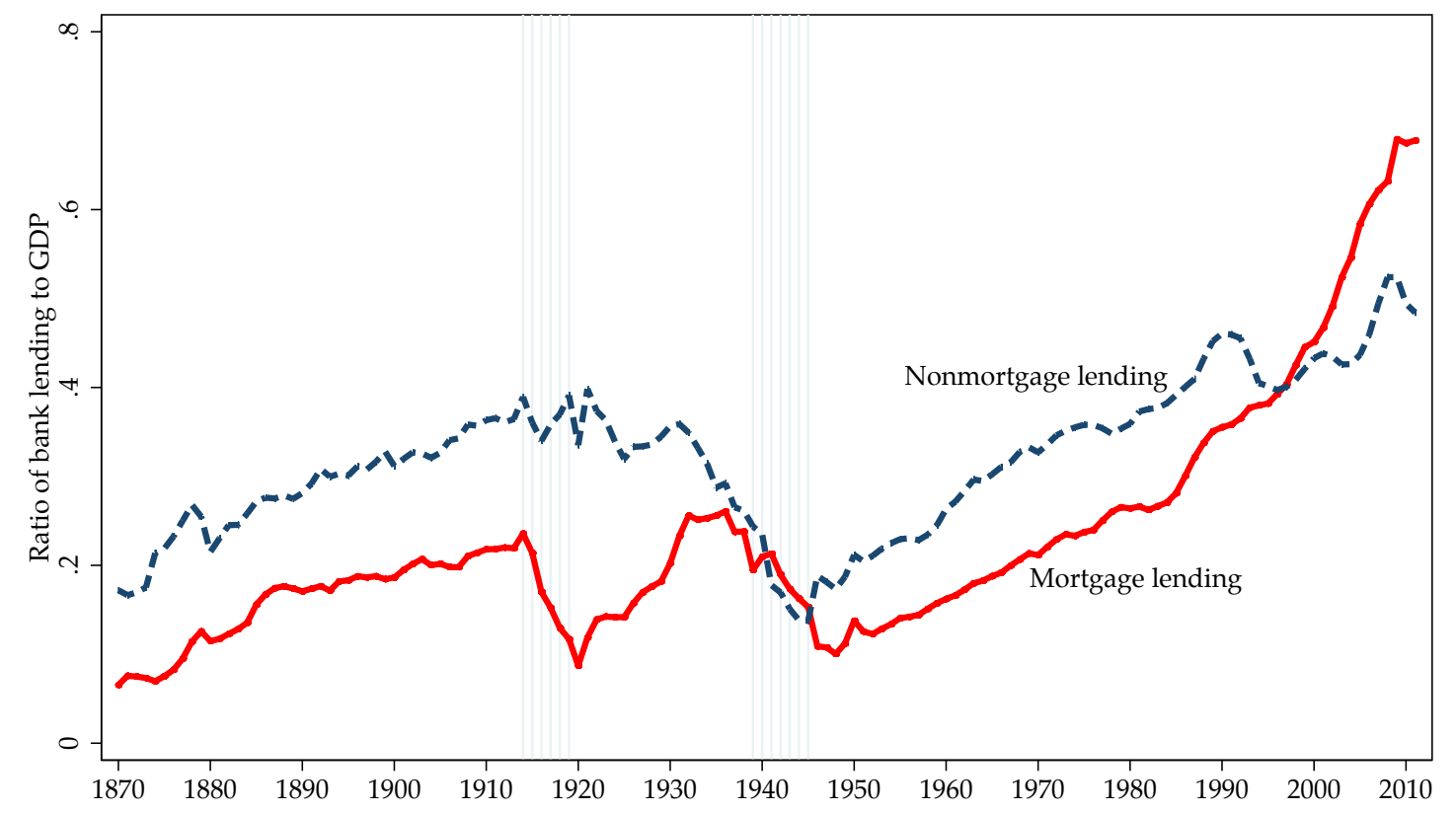

Notes: Mortgage (residential and commercial) and non-mortgage lending to the business and household sectors. See text. The years of the two world wars are shown with shading.

substantial share of the increase in private sector debt levels in the past decades-a process often referred to as financialization - has been driven by the increase of real estate credit. Unsecured lending to the business sector has remained largely stable. Non-mortgage bank lending has hovered in the $40 \%-50 \%$ range as a ratio to GDP on average.

As a result of these trends, mortgage credit now accounts for nearly three fifths of the typical balance sheets of banks in advanced economies while only two fifths go to businesses and consumers for purposes other than the purchase of real estate. From an economic point of view, this is noteworthy for at least two reasons. First, textbook models of the banking sector assume that the role of the banking sector is to intermediate household savings into business investment. This was a useful description of the activities of the financial sector in the first half of the 2oth century, but it is no longer true today. The banking sector chiefly intermediates savings between households for the purpose of real estate acquisition. Second, the key economic function of banks no longer seems to correspond to their business model. The advantage of banks relative to direct financial intermediation is to reduce information asymmetries through screening and monitoring of borrowers. However, this function is arguably much more important for business financing than for standardized mortgage contracts. 
Figure 2: Bank mortgage and non-mortgage lending to GDP, 1870-2011, 17 countries detail

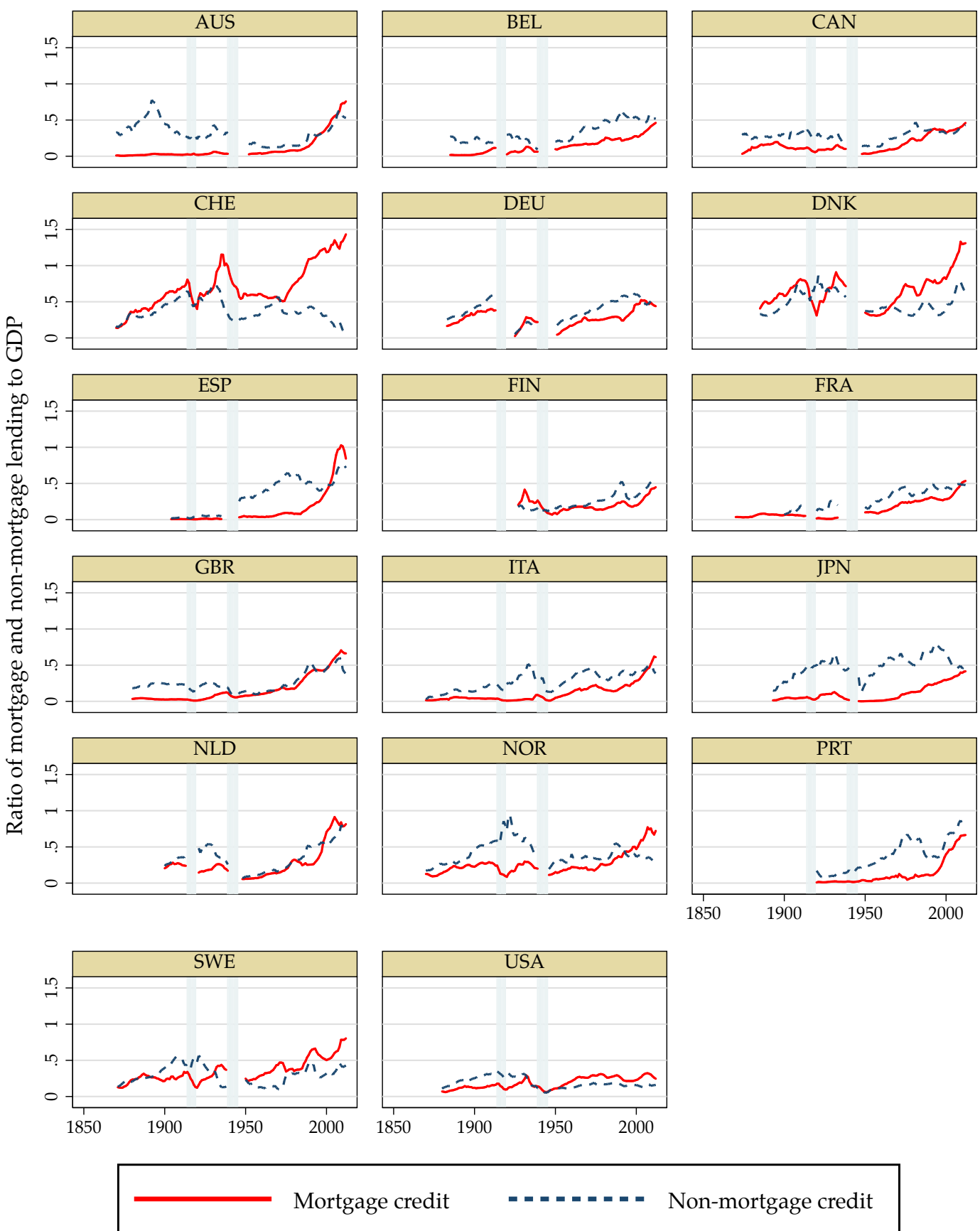

Notes: Mortgage (residential and commercial) and non-mortgage lending to the business and household sectors. See text. The years of the two world wars are shown with shading. 
Figure 3: Trends in home ownership rates for six countries

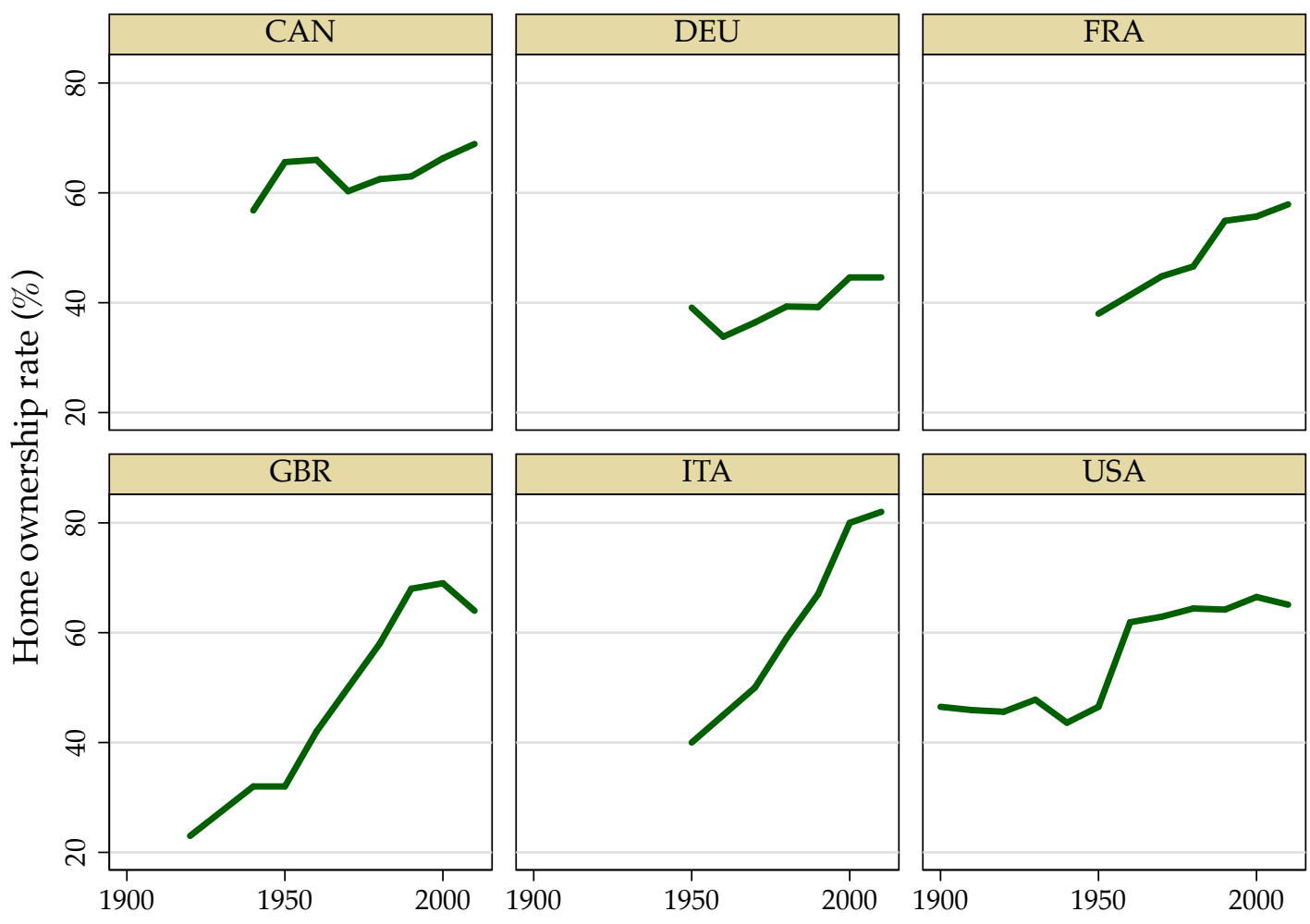

Notes: See text.

The rise in mortgage credit over the second half of 2oth century has financed a substantial expansion of home ownership in Western economies. Karl Marx noted in Das Kapital that according to the census of 1861 there were 20 million people living in England and Wales whereas the number of home owners was given as 36,000 . Back then, far fewer than $1 \%$ were among the fortunate who owned property. In our times, the debate about the top $1 \%$ is back, but it is clear that home ownership is distributed much more widely today with home ownership rates north of 60\% (see, e.g., Bonnet et al. 2014).

By the 1920 s home ownership rates in England had already increased to about $20 \%$ from the days of Marx's writing. In the U.S. and thanks to the 1944 G.I. Bill, home ownership rates would cross the 50\% mark shortly after WW2. Explicit government policies and generous subsidies to boost home ownership were, by and large, a widespread phenomenon of the postwar decades. Today the view that home ownership is a key constituent of national identity is widely shared and supported by growing government intervention. Figure 3 illustrates this pervasive increase in home ownership. 
Figure 4: Real home prices, relative to CPI, in the 2oth century
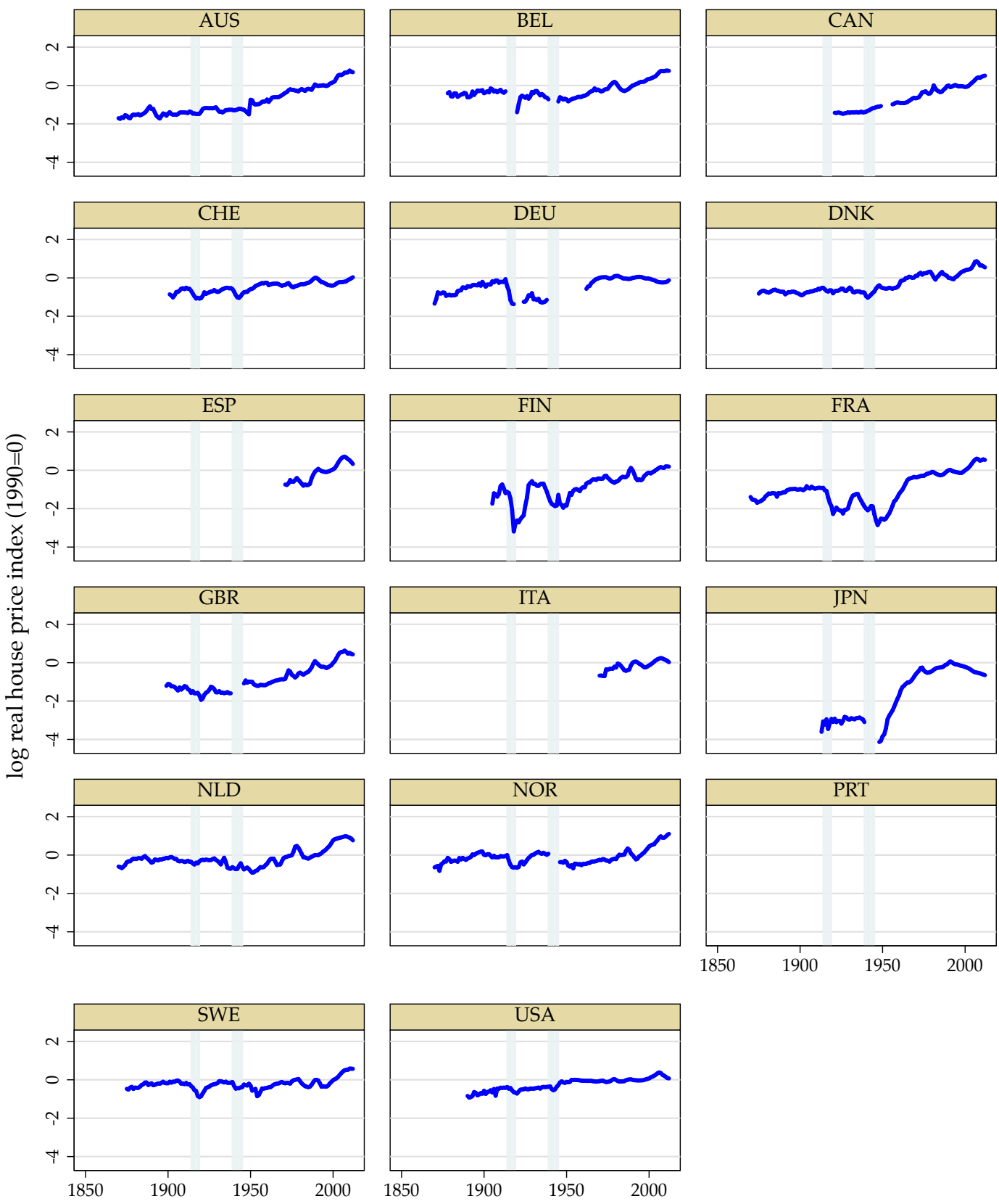

Notes: Nominal house price index divided by consumer price index. See text. The years of the two world wars are shown with shading. 
Figure 5: Home prices relative to income per capita in the 2oth century
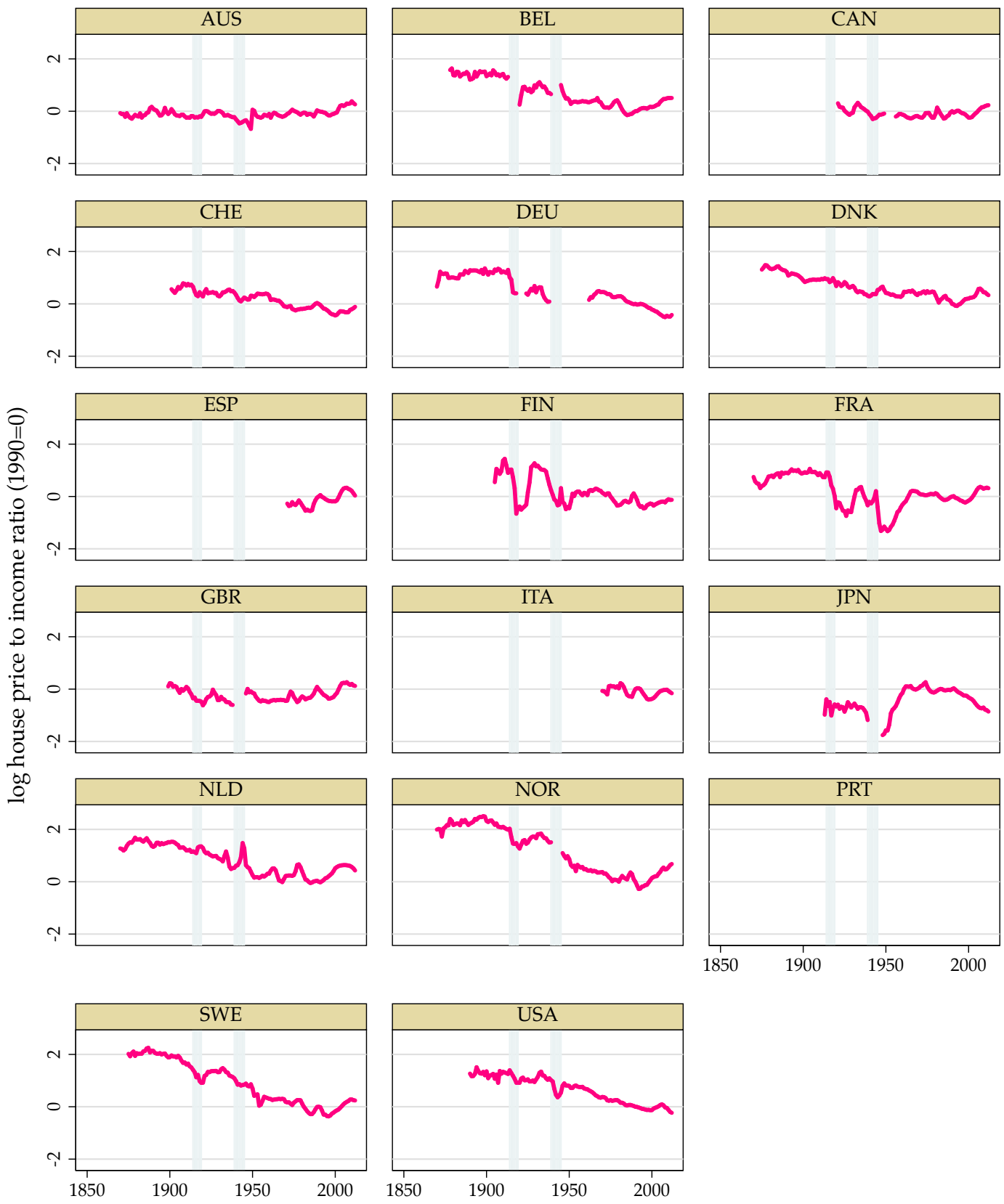

Notes: Real CPI-based house price divided by real income per capita. See text. The years of the two world wars are shown with shading. 
The growth of mortgage credit has not only led to an expansion of home ownership, it has left its mark on house price dynamics. The data collected and analyzed by Knoll (2014) show that the path of global house prices in the 2oth century has not been continuous. Real house prices, deflated with the consumer price index (CPI), remained stable from 1870 until the middle of the 2oth century after which they gradually grew, as Figure 4 shows. Relative to income, house prices initially fell in many countries before stabilizing or increasing over the past few decades. This is displayed in Figure 5 . Over the last 140 years, house prices have risen significantly relative to the price of consumption goods, but have lagged real income growth.

Figure 5 also shows that there are large swings in house price to income ratios. Periods of pronounced increases are often followed by abrupt corrections. Later in the paper we study if such swings can be explained by changes in credit conditions. In addition, Figure 5 shows that there is considerable heterogeneity in house price trends across economies that otherwise have similar characteristics and comparable long-run growth performance. The international experience can be broadly synthesized into three categories. House prices in Australia have increased more than income since 1870. In contrast, house prices have lagged income growth by a wide margin in countries such as Belgium, Sweden, Germany, and the U.S. Finally, for a third group of countries consisting of Canada, the U.K., Japan and possibly France, house prices have mostly grown on a par with income.

\section{A Eurozone parable}

What role have monetary conditions played in mortgage credit expansions and house price booms? Later sections proceed at some length with a formal econometric investigation. Here we motivate the analysis using a recent dramatic example based on the divergent macroeconomic and financial outcomes of the core and periphery of the Eurozone ${ }^{1}$

Upon the creation of the Eurozone in 1999, member states signed up to a common monetary policy administered by the ECB. The loss of monetary policy autonomy was an extreme version of the trilemma: with capital mobility enforced by treaty within the EU, and with exchange rates irrevocably fixed by the no-exit feature of the euro, each member state had no scope to set monetary conditions to suit the outlook for their macroeconomy. Such a choice might make economic sense under the tradeoffs embodied in the theory of optimum currency areas (Mundell 1961; Kenen 1969), but it would still be a tradeoff, and some cost would attach to the sacrifice of monetary autonomy. But how big a cost?

Absent perfectly synchronized business cycles and frictionless adjustments, common monetary policy administered by the ECB meant that for some countries monetary

\footnotetext{
${ }^{1}$ For background see, e.g., Allen et al. (2011), Lane (2012), and O'Rourke and Taylor (2013).
} 
conditions would be "too loose," whereas for some others they would be "too tight." Booming economies would be encouraged to grow, slumping economies to decline, resulting in greater real economic instability $\left.\right|^{2}$

However, business-cycle models that include an explicit role for the financial sector suggest that other dangers lurk. If transmission works through the credit channel of monetary policy, then countries facing excessive monetary ease would see larger credit booms than normal. Moreover, these effects could be magnified via cross-border capital flows, and with the possibility that these credit booms could spill over into asset prices, altogether elevating the risk of financial instability. Prima facie, the events in the Eurozone in the 1999-2008 pre-crisis phase seem to conform with this narrative.

Figure 6 shows some salient features of the Eurozone episode. The focus is on two crisis countries, Ireland and Spain, plus Germany. Before the crisis, Ireland and Spain had fast-growth economies, credit booms with large increases in mortgage lending, and rapid housing price increases (in real and nominal terms, and relative to income per person). After 2008 all of these trends went into sharp reverse, with a banking crisis in each country, deep depressions and high unemployment, and extremely high levels of fiscal distress. Quickly worsening fiscal positions arose, driven by lost output and by banking sector bailout and recapitalization costs. In contrast Germany grew more slowly in the 1999-2008 period, had no credit, mortgage, or housing booms, and had a more moderate recession in 2008 soon followed by recovery and a return to growth. Banking crisis effects were still present in Germany (some banks suffered losses on U.S. subprime and euro periphery exposures) but these problems were shrugged off and bailout costs easily absorbed by a fiscal position that started strong and did not deteriorate very much.

Figure 6, panel (a) shows the interest rate environment of the three countries and it accords with the standard narrative view of the key mechanisms. Based on a study by Malkin and Nechio (2012), we show the "optimal" Taylor-rule implied policy interest rates for the three countries against the actual ECB policy rate for the 1999-2007 period. Given the rapid output growth and above target inflation in Ireland and Spain, the Taylor rule policy rate for these economies would have been much tighter, perhaps 500 basis points (bps) tighter and sometimes more. In contrast, relatively slow growth and low inflation in Germany meant that its Taylor rule policy rate would have been slightly looser than that chosen by the ECB, maybe by as much as 100 bps on average. Viewed as a natural experiment, the question is whether these differences in monetary policy treatment led to different outcomes in Ireland and Spain using Germany as control.

Panel (b) of Figure 6 shows that outcomes in the credit markets differed by treatment.

\footnotetext{
${ }^{2}$ The Mundellian output volatility effects of fixed-versus-floating exchange rate regime choice are well known. On the empirical evidence see di Giovanni and Shambaugh (2008).
} 
Figure 6: Short-term interest rates, credit growth and house prices in Ireland, Spain, and Germany

(a) Taylor rule and actual policy interest rates (\% per year)

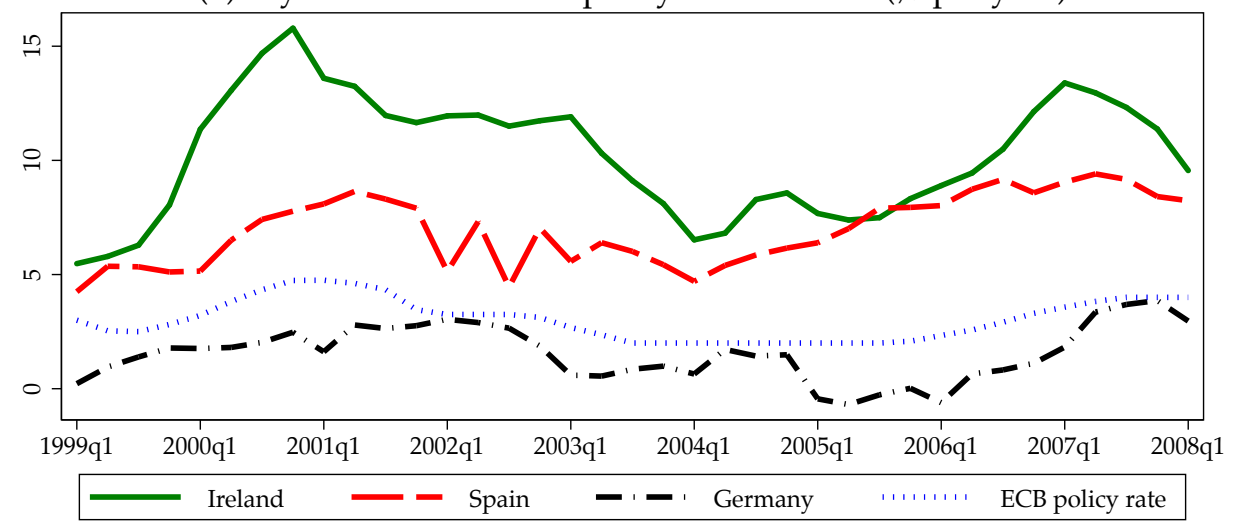

(b) Mortgage lending to GDP ratio (\%)

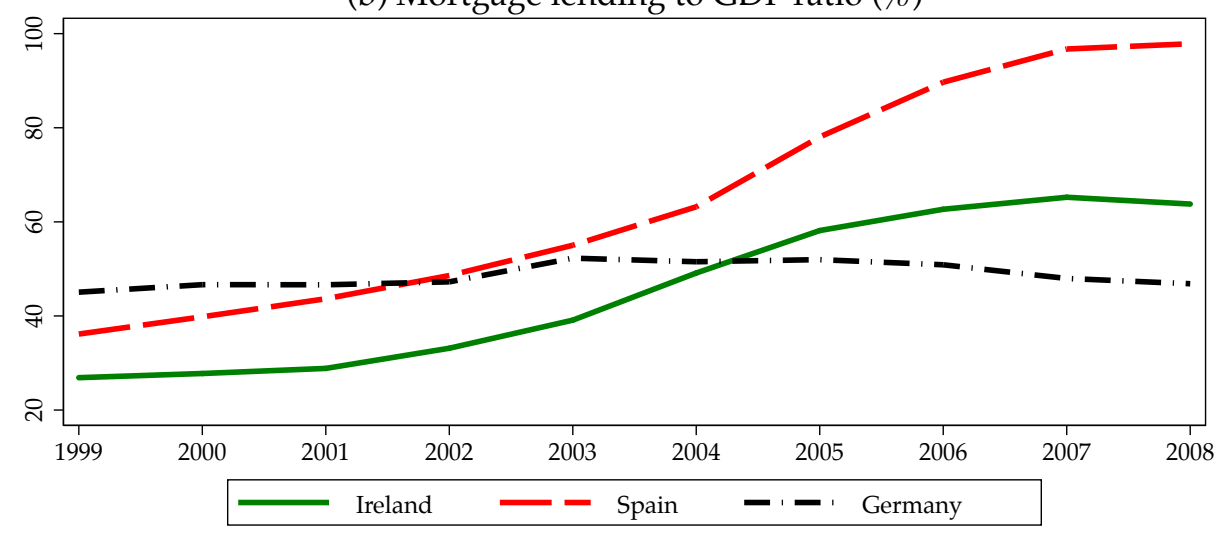

(c) House price to income ratio $(1999 \mathrm{q} 1=100)$

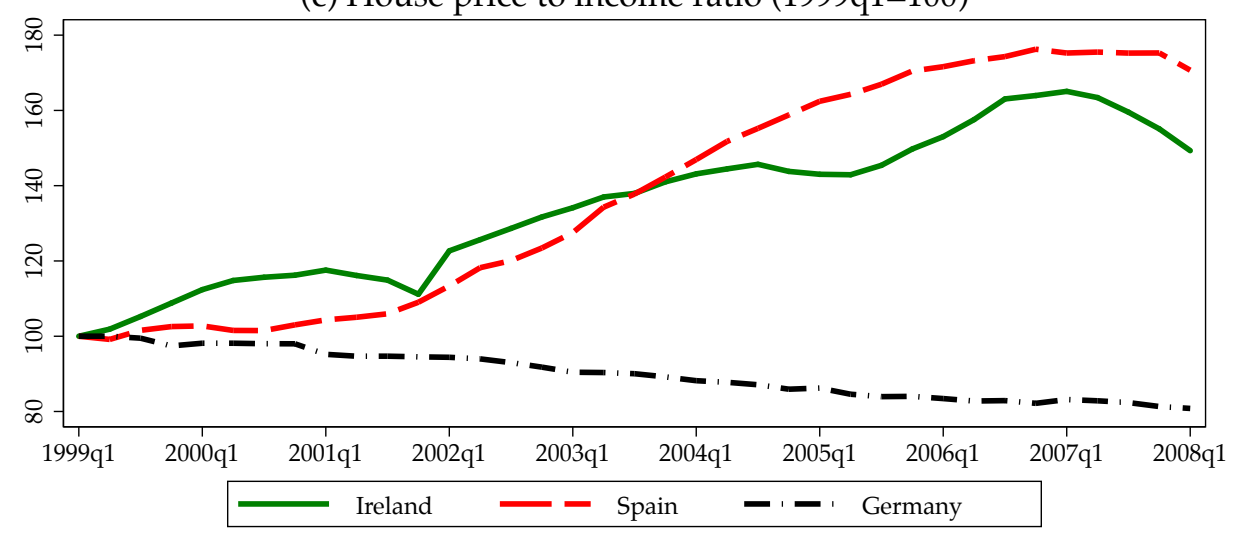

Notes: Reproduced from Malkin and Nechio (2012). See text. 
In Ireland and Spain a large expansion in private debt was driven in large part by the growth of real estate backed mortgages. The level of mortgage debt to GDP in each country doubled in the space of about eight years. Meanwhile, the level of mortgage debt to GDP was stable in Germany over the entire period at about 50\% of GDP.

Panel (c) of Figure 6 shows the very different outcomes in house price trends. The house price to income ratio was nearly stable in Germany over the entire period, declining slightly by $20 \%$ over the decade. In contrast, house price to income ratios in Ireland and Spain rose by $65 \%-75 \%$ over the same time frame.

These data provide some support to the hypotheses, often asserted in analyses of the Eurozone crisis, that periphery countries experienced an exogenous monetary easing which went on to fuel credit and housing price boom and bust cycles-ending in economic crises and output disasters for countries like Ireland and Spain. Yet can we establish a causal link between monetary conditions on the one hand, and mortgage and house price boom-bust cycles, as well as financial instability, on the other hand? More to the point, can we get formal statistical evidence from a large body of empirical macroeconomic evidence that looks systematically at many episodes over time and space rather than a case study based on a sample of three countries? The remainder of this paper will try to answer both of these questions in the affirmative.

\section{EXOGENOUS PERTURBATIONS TO MONETARY CONDITIONS: THE TRILEMMA AS A NATURAL EXPERIMENT}

Using short-term interest rates as a proxy for monetary conditions, what is the causal link to mortgages and house prices based on our large sample of macro-financial data covering the history of advanced economies since 1870? The key empirical hurdle in answering this question is that home interest rates may be endogenously determined. Averting simultaneity bias requires identifying movements of the home interest rate that are not the result of the reaction by local policymakers to domestic economic conditions, including output, inflation, and the evolution of credit and housing prices.

The macroeconomic policy trilemma offers a possible solution to the identification conundrum. This foundational proposition of international macroeconomics states that a country cannot simultaneously pursue the three mutually incompatible policy goals

of fixed exchange rates, capital mobility, and monetary policy autonomy (Obstfeld and Taylor 2004). It must give up one of the three goals, or equivalently choose to pursue only two out of the three. A simple corollary of interest parity, the trilemma has been central to open economy macroeconomics since the work of Mundell and Fleming, and in the last decade has seen extensive empirical testing and validation (Obstfeld, Shambaugh, 
and Taylor 2004, 2005; Aizenman, Chinn, and Ito 2008; Klein and Shambaugh 2013).

Suppose the home country $i$ at time $t$ has either a fixed (pegged) or flexible (floating) exchange rate with respect to some other base country. This is denoted by the variable $P E G_{i t}=1$ and $P E G_{i t}=0$, respectively. Suppose the home country $i$ at time $t$ is either open or closed to international capital markets. This is denoted by the variable $K O P E N_{i t}=1$ and $K O P E N_{i t}=0$, respectively.

Let $r_{i t}$ denote the short-term nominal interest in the home country, and let $r_{i t}^{*}$ denote the short-term nominal interest set by policymakers in country $i$ 's base country. Note that the home country index $i$ is used since base countries differ by $i$. Furthermore, changes over the period are denoted $\Delta r_{i t}$, and $\Delta r_{i t}^{*}$, respectively. We denote with $X_{i t}$ a set of domestic macroeconomic controls used in determining the home interest rate in the absence of a peg. A simple algebraic expression of the trilemma suitable for our empirical application sets out the observed change in the home interest rate as a function of the change in the base country interest rate and the configuration of the exchange rate regime and capital mobility:

$$
\Delta r_{i t}=a+b\left[P E G_{i t} \times K O P E N_{i t} \times \Delta r_{i t}^{*}\right]+\Theta X_{i t}+u_{i t} .
$$

To develop intuition, think about two polar cases. In the case of a floating regime or capital immobility, there need be no correlation at all between home and base rates, $P E G_{i t} \times K O P E N_{i t}=0$ and then $r_{i t}$ and $r_{i t}^{*}$ would be completely delinked. In the case of a truly hard peg with capital mobility $d P E G_{i t} \times K O P E N_{i t}=1$ and with perfect correlation $(b=1)$ then changes in the observed home and base rates, $r_{i t}$ and $r_{i t}^{*}$ would be equalized. A possible risk premium would be captured by the intercept when $a \neq 0$, but the simple theory would entail a perfect pass-through with the coefficient $b=1$ in the pegged case. Other influences on the home interest rate are captured by the controls $X_{i t}$. The error term $u_{i t}$ is assumed to be well behaved.

In practice, the dichotomy between fixed and flexible regimes is not as clean and intermediate regimes muddy the simple story described above. Likewise, capital mobility may not be properly captured in a binary variable, but rather in by a continuous measure, as we assume below. The implications for the coefficient $b$ then depend on the nature of local monetary policy reaction within whatever room for maneuver the regime permits. In a target-zone model with a home central bank that can "lean against the wind" theoretical simulations by Obstfeld, Shambaugh, and Taylor (2005) show that the coefficient $b$ may be below one, but still above zero.

For our analysis, the trilemma equation (1) provides a method for identifying home interest rate perturbations that are unrelated to local economic conditions. Base countries, 
such as the U.S. in the Bretton Woods era, have monetary policy autonomy by definition. But, as conventionally understood, their authorities would pay no attention whatsoever to economic conditions in partner countries when making policy choices.

The examples are legion. Famously, the U.S. decision to raise rates in 1927-28 in reaction to local asset market conditions imposed stress on the U.K. and other countries trying to cling to the interwar gold standard. Over a longer period so did the steady tide of gold reserves flooding into a Banque de France which was all too eager to sterilize them (Eichengreen 1992; Ahamed 2009; Irwin 2010). At the G-10 Rome meetings in 1971, U.S. Treasury Secretary John Connally declared to the world that "the dollar is our currency, but it's your problem." In June 1972 President Richard Nixon expressed the same sentiment rather more colorfully, caught on the ever-running Watergate tapes, when he was asked by aide H. R. Haldeman about an incipient currency crisis in Italy and blurted out his famous response: "Well, I don't give a shit about the lira."

In the final days of Bretton Woods, it was the turn of the U.S. to fall under exchange rate pressure, but in the dead of the night the German government withdrew its support, allowing the dollar to fall against the mark, a decision that was later justified by Chancellor Schmidt with an appeal to the arcane legal doctrine ultra posse nemo obligatur. The same problem of cooperation under fixed exchange rates resurfaced in the 1992 ERM crisis when, at the September 5 meeting in Bath, the German Finance Minister Theo Waigel replied to the repeated pleas of his British counterpart, Norman Lamont, for the Bundesbank to loosen monetary policy: "My dear Lamont, you have asked that question four times...if you ask again, I will get our helicopter ready to take us back.'3

Still today the recurrent mutterings about currency wars in recent years tell the same story: when considering not just the plight of unilateral dollarizers such as Panama, Ecuador, or El Salvador, but even the general spillovers from U.S. monetary policy to the quasi-"dollar bloc" of emerging economies, especially India and China, players on all sides harbor few illusions that the Fed will shape its interest rate policies to suit conditions in far away countries.

In sum, to peg is to sacrifice monetary policy autonomy, at least to some degree. Given this understanding of the key constraints in past and present international monetary regimes it is natural for us to treat the term $z_{i t}=\left[P E G_{i t} \times K O P E N_{i t} \times \Delta r_{i t}^{*}\right]$ on the righthand side of equation (I) as an exogenous influence on local monetary conditions in the home economy, notwithstanding other effects captured by the rest of the terms in the equation. Thus $z_{i t}$ will serve in what follows as the instrumental variable for changes in home interest rates, and will permit us to identify causal relationships from rates to mortgage credit and to house prices.

\footnotetext{
${ }^{3}$ See Buiter, Corsetti, and Pesenti (1998, 14).
} 
Table 2: Selection of base country short-term interest rate for pegged exchange rates by era

\begin{tabular}{|c|c|c|c|c|}
\hline Base country & Pre-WWI & Interwar & Bretton Woods & Post-BW \\
\hline $\begin{array}{l}\text { UK } \\
\text { (gold standard/BW base) }\end{array}$ & $\begin{array}{c}\text { All } \\
\text { countries }\end{array}$ & & $\begin{array}{l}\text { Sterling bloc: } \\
\text { AUS, CAN }\end{array}$ & \\
\hline
\end{tabular}

UK/US/France composite (gold standard base)

USA

(BW / Post-BW base)
All

countries

Germany

All other

(EMS/ERM/

All other

Dollar bloc:

countries

AUS, CAN, CHE, JPN, NOR

Eurozone base)

Notes: See text and Obstfeld, Shambaugh, and Taylor (2004, 2005).

The formal definition of the instrumental variable $z_{i t}$ consists of multiplying the change in relevant base country short-term interest rate $\Delta r_{i t}^{*}$ by the product of $P E G_{i t}$ and of KOPEN $N_{i t}$. The peg indicator equals 1 when the home country is pegged to the base country in both year $t$ and year $t-1$. For the sample of countries we study, a description of the relevant base countries in each historical era is presented in Table 2. Prior to WW2, peg codings are taken from Obstfeld, Shambaugh, and Taylor (2004; 2005). After WW2 they are gleaned from Ilzetzki, Reinhart, and Rogoff (2008) and updates thereto. Prior to 1914 we treat the U.K. as the base for everyone, and after 1945 we treat the U.S. as the base for everyone, with the exception of EMS/ERM/Eurozone countries for which Germany is the base after 1973. In the interwar period, the choice of a suitable base country is more challenging and subjective given the instability of the interwar gold standard period; we follow Obstfeld, Shambaugh, and Taylor (2004) in using a hybrid "gold center" short-term interest rate, which is an average of U.S., U.K., and French short term rates depending on which of the three countries was pegged to gold in a particular year; our results are not sensitive to this choice and we replicate our findings using any one of these three countries as the sole interwar base as in Obstfeld, Shambaugh, and Taylor (2004). The capital mobility indicator is based on the index (from o to 100) in Quinn, Schindler, and Toyoda (2011). We use a continuous version of their index rescaled to the unit interval, with o meaning fully closed and I fully open. 
Figure 7: The trilemma-based IV: changes in short-term interest rates in home and base countries

(a) Pre-WW2

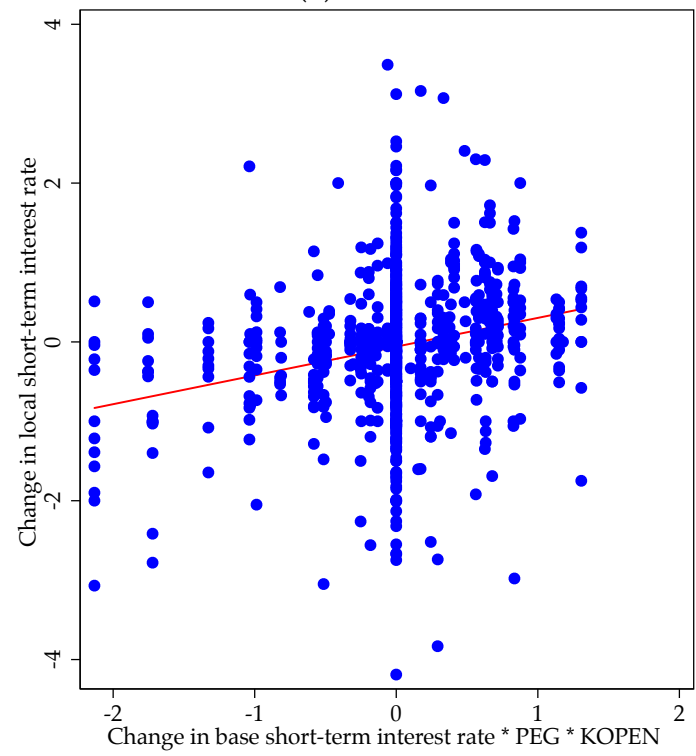

(b) Post-WW2

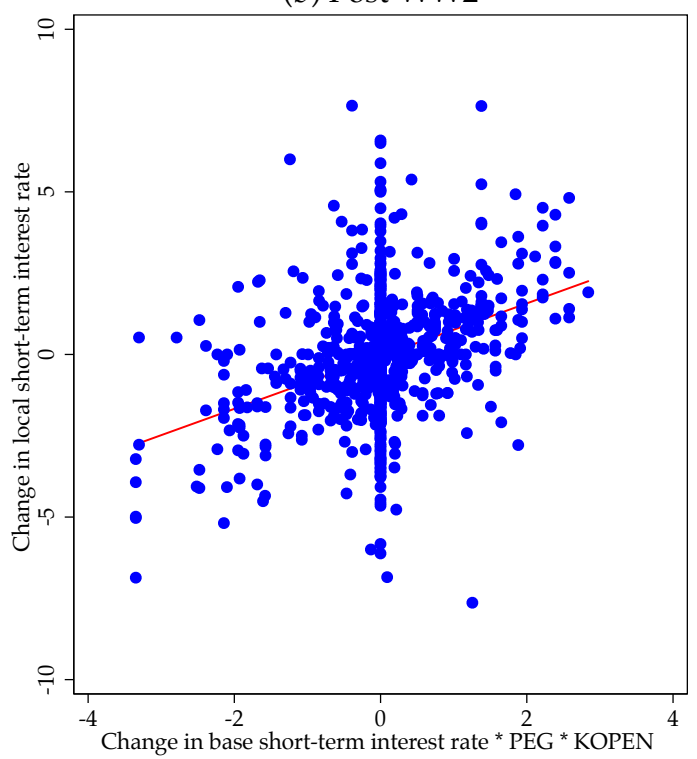

Notes: See text and Table 3, panel (a), columns (2) and (3).

Figure 7 and Table 3 verify that if $z_{i t}$ has the potential to be a valid instrument, for all the reasons given above, then it is certainly not a weak instrument. The scatter plots in Figure 7 are simple bivariate plots of the change in the home short rate $\Delta r_{i t}$ against the putative instrument $P E G_{i t} \times K O P E N_{i t} \times \Delta r_{i t}^{*}$, for our panel dataset, looking separately at both the pre-WW2 and post-WW2 samples. That is, we estimated (I) and no controls $X_{i t}$, as in Panel (a) and Columns (2) and (3) of Table 3, then plotted the data and the line of best fit. The correlations are seen to be strong; the slope coefficients $b$ in each case are significant at the $1 \%$ level. The F-statistics exceed 15 in all cases, and exceed 60 in the full sample. The coefficients $b$ in each subsample, and in the full sample, are close to $1 / 2$ rather than 1 , so the pass-through from base to home rates is not one-for-one, but is significant; these results very closely match those in Obstfeld, Shambaugh, and Taylor (2004; 2005).

We now move on and the apply the instrumental variable $z_{i t}$ to the central estimation problem in our paper. In a setting like ours, the approach of using exchange rate regimes to identify exogenous shocks has great promise as a way of estimating policy impacts, and it builds on several applied works which embrace a similar logic: di Giovanni and Shambaugh (2008) use the same instrument to look at output volatility in fixed and floating exchange rate regimes; Ilzetzki, Mendoza and Végh (2013) partition countries by exchange rate regimes to study the impacts of a fiscal policy shock. In this paper 
Table 3: Relationship between change in short-term interest rates in home and base countries Dependent variable: change in short-term interest rates in home county, $\Delta r_{i t}$.

\begin{tabular}{lccccc}
\hline \hline & $(1)$ & $(2)$ & $(3)$ & $(4)$ & $(5)$ \\
& All years & Pre-WW2 & Post-WW2 & Pre-1914 & Interwar \\
\hline$P E G_{i t} \times$ KOPEN $_{i t} \times \Delta r_{i t}^{*}$ & $0.68^{* * *}$ & $0.36^{* * *}$ & $0.81^{* * *}$ & $0.32^{* * *}$ & $0.52^{* * *}$ \\
& $(0.08)$ & $(0.09)$ & $(0.09)$ & $(0.08)$ & $(0.13)$ \\
& & & & & \\
Constant & $-0.08^{* *}$ & $-0.11^{*}$ & $-0.05^{* *}$ & -0.01 & $-0.33^{*}$ \\
& $(0.03)$ & $(0.06)$ & $(0.02)$ & $(0.01)$ & $(0.18)$ \\
\hline$R^{2}$ & 0.074 & 0.013 & 0.147 & 0.066 & 0.004 \\
F-statistic & 64.28 & 17.34 & 79.63 & 15.51 & 16.61 \\
Observations & 1875 & 876 & 999 & 602 & 274 \\
\hline \hline
\end{tabular}

Notes: ${ }^{*} p<0.1{ }^{* *} p<0.05,{ }^{* * *} p<0.01$. Country-based cluster-robust standard errors in parentheses. Fixed effects omitted. World wars omitted. See text.

we use this strategy to gain a clean identification of the workings of the credit channel and its implications for mortgage and house price booms and busts over the course of macroeconomic history.

\section{INSTRUMENTAL VARIABLE LOCAL PROJECTIONS}

Across different periods in history, countries with fixed exchange regimes often saw fluctuations in short-term interest rates unrelated to home economic conditions. This natural pseudo-experiment provides an exogenous source of variation in home shortterm interest rates. This section discusses how we exploit this feature to identify the dynamic multipliers of mortgages and house prices in response to these pseudo-natural experiments in the short rate.

The empirical strategy combines the local projection approach (Jordà 2005) with instrumental variable (IV) methods. Recent papers that have used this particular combination of procedures include Leduc and Wilson (2013) and Owyang, Ramey and Zubairy (2013). Recall that the data that we will analyze are a long panel of 14 countries observed over roughly 140 years. However, the panel is not balanced because data availability varies by country. We explain the details of our dataset in the appendix. Note also that we exclude the two world wars.

Let $\Delta_{h} y_{i t-1}=y_{i t+h}-y_{i t-1}$ denote the response variable of interest, for example, the change in house prices (measured as the log of the ratio of real house prices to income per capita) from the base year $t-1$ up to year $t+h$ with $h=0,1, \ldots, H$. The subindex $i$ denotes the country. Let $\Delta r_{i t}$ denote the change in the home short-term interest rate, although in general it refers to any variable whose perturbations we want to trace and for 
which instruments are available. We denote $z_{i t}$ as the instrumental variable introduced in the previous section and based on whether countries peg their currency to a base country and impose capital controls or not.

Next, consider two additional vectors of variables. The vector $\Delta W_{i t}$ includes all the variables in the system observed at time $t$ for country $i$ except for $\Delta y_{i t}$ (given our timing convention, this is the first left-hand side variable) and $\Delta r_{i t}$, which we explicitly instrument for. We will discuss the specific variables included in the analysis momentarily. In addition, the vector $\Delta X_{i t-1}$ contains the lags of all the elements in $\Delta W_{i t}$ as well as the lags of $\Delta y_{i t}$ and $\Delta r_{i t}$. The notation $\Delta$ indicates that the variables in the system are all expressed as first differences.

Using these variable definitions, we are interested in estimating the dynamic multipliers of $\Delta_{h} y_{i t-1}$ for $h=0,1, \ldots, H$ to an exogenous perturbation in $\Delta r_{i t}$. Identification of this exogenous perturbation is achieved in two ways. First, by using a rich set of controls to isolate the selection mechanism based on observables. This is done via the auxiliary vectors $\Delta W_{i t}$ and $\Delta X_{i t-1}$. Specifically, notice that the vector $\Delta W_{i t}$ has the same timing as $\Delta r_{i t}$. This is intentional, so as to manage the effect of home conditions observed within the year. The second basis for identification uses the instrumental variable $z_{i t}$ for $\Delta r_{i t}$ to account for selection based on unobservable factors. In practice, both sets of variables (controls and instrument) are used in the first stage regression, of course. Below we discuss the properties of the instrument in the context of this first stage regression.

Using these variable definitions, the specification of the local projections is

$$
\Delta_{h} y_{i t-1}=\alpha_{i}^{h}+\beta^{h} \Delta r_{i t}+\Delta W_{i t} \Gamma^{h}+\Delta X_{i t-1} \Phi^{h}+u_{i t+h}
$$

which can be estimated by instrumental variables regression methods using $z_{i t}$ as the additional instrument for $\Delta r_{i t}$. The $\alpha_{i}^{h}$ are country-fixed effects and in the estimations below we use country-based cluster-robust standard errors. The dynamic multipliers of interest are therefore the IV estimates of $\beta^{h}$ for $h=0,1, \ldots, H$. We generically designate these as LP-IV coefficients, short for local projection instrumental variables.

Estimates of the specification in expression (2) reported below therefore include a rich set of controls contemporaneously and in the lag structure. The objective is to stack the odds against our instrument as much as possible in the following sense. We want to isolate fluctuations in the short-term interest rate that are not explained by home economic conditions, but rather are correlated with short-term fluctuations in the base country (in situations where the home economy pegs its currency). Including a rich set of domestic controls soaks up variation in the base country's short rate related to the home economy. This is the best insurance against finding that the estimated responses reflect 
endogenous fluctuations of the response variable given the data that we have. We will show momentarily that even with a saturated specification, the instrument remains highly relevant in most cases.

A truly exogenous instrument would allow us to estimate the responses without having to account for observable controls. In this case correlation between the base and the home economies makes including controls unavoidable. Unfortunately, we are unable to explicitly test for the exogeneity of the instrument using a test of over-identifying restrictions. Expression (2) is just-identified. Where appropriate, we report the results both with and without controls (the latter are provided as a robustness check). Data availability imposes considerable restrictions on the pre-WW2 sample. As a result, it is useful to show the results that omit controls but use a longer sample to check the estimates against those from the more limited sample. Moreover, we also provide (again, as a robustness check) a comparison of the results based on OLS estimates of expression (2) to characterize the bias in the OLS estimates.

\section{MONETARY CONDITIONS, CREDIT GROWTH, AND HOUSE PRICES}

Section 2 discussed secular trends in mortgage lending that suggest bank lending experienced a considerable shift toward real estate financing after WW2. This section focuses instead on short-run fluctuations. Our instrument captures movements in short-term interest rates relative to movements that would have likely prevailed under a floating exchange regime and full control of domestic monetary policy.

Our analysis proceeds logically in sequential steps. First, we examine how persistently exogenous perturbations propagate to short-term interest rates. The rational expectations hypothesis of the term structure suggests that expectations on future short-term rates, adjusted for risk, drive longer term-rates. Therefore, next we trace how short-term rate fluctuations reverberate to long-term rates. Long-term rates tend to be very highly correlated with mortgage rates and therefore provide a good proxy measure for the price of mortgages (for which we do not have direct observations). Thus, we examine how the quantity of mortgages (normalized by GDP) responds to our pseudo-experiment. Ultimately, the availability of credit makes home buying more accessible. Higher demand for houses through cheaper financing tends to put upward pressure on home prices. The last link in the chain of events thus consists of characterizing the response of house prices to the shock in the short-term rate. 


\subsection{The instrument is relevant}

As a first check, we evaluate the strength of the instrument introduced in Section 4 in the context of expression (2). We estimate the first stage regression of $\Delta r_{i t}$ on $z_{i t}$ and the other regressors in expression (2) including country-fixed effects. Then we report the F-statistic for the coefficient on $z_{i t}$ constructed with country-based, cluster-robust standard errors. We note that since we only have one endogenous regressor, typical tests of instrument relevance, such as Kleibergen and Paap's (2006) rank test, are roughly equivalent to the heteroskedasticity and autocorrelation robust Wald tests from OLS in the first stage. Due to gaps in data availability, we obtain different estimates of the Kleibergen and Paap (2006) statistic when we report our response estimates in Table 5 below (and later when we report robustness checks). We provide here simple first stage regression results to illustrate the instrument's basic features.

The four response variables of interest include: (1) the short-term interest rate; (2) the long-term interest rate; (3) the ratio of mortgage loans to GDP; and (4) the log ratio of house prices to per capita income. When these variables are used as a left-hand side variable in expression (2), we take the h-difference $\Delta_{h} y_{i t-1}$ described earlier. When the variables enter as controls, these variables enter as simple first differences. All of these variables are measured in percent change to facilitate the interpretation of the results.

Additional controls include: (i) the growth rate of real GDP per capita; (ii) the CPI inflation rate; (iii) the investment to GDP ratio; (iv) the ratio of non-mortgage lending to GDP; and (v) the ratio of the current account to GDP. We include up to two lags of each variable in the vector $\Delta X_{i t-1}$. In what follows we report the $\beta^{h}$ coefficients in expression (2) but omit estimates of the fixed effects and the control set for brevity. We implement the analysis for the full sample and later as a robustness check, we split the sample at World War 2. In Section 2 we argued that the major developments in mortgage lending took place starting in the second half of the twentieth century.

Table 4 reports first-stage regression results. The short rate is regressed on our instrument $\Delta z_{i t}$. We report two regressions. In the first block of results (columns 1-3) we omit the controls, in the second block (columns 4-6) we include them. The reason is that the sample sizes can vary quite a bit. Some of the controls are not available for some countries, specially in the first part of the sample. We consider three samples: all years, and the pre- and the post-WW2 years. In all cases we omit the world wars.

The results in Table 4 provide tangible intuition about the strength of the instrument. The instrument is relevant, although a bit weaker in the pre-WW2 era (columns 2 and 5). Even after adding a very rich set of controls and fixed effects (columns 4-6), the instrument remains significant across samples with high F-statistics (and hence significant coefficient 
Table 4: First-stage regression of the short-term interest rate on the instrument

\begin{tabular}{|c|c|c|c|c|c|c|}
\hline & \multicolumn{3}{|c|}{ No Controls } & \multicolumn{3}{|c|}{ With Controls } \\
\hline & (1) & (2) & (3) & (4) & (5) & (6) \\
\hline & All & Pre- & Post- & All & Pre- & Post- \\
\hline & Years & WW2 & WW2 & Years & WW2 & $\mathrm{WW}_{2}$ \\
\hline IV Coefficient & $\begin{array}{c}0.68^{* * *} \\
(0.06)\end{array}$ & $\begin{array}{c}0.36^{* * *} \\
(0.11)\end{array}$ & $\begin{array}{c}0.81^{* * *} \\
(0.06)\end{array}$ & $\begin{array}{c}0.43^{* * *} \\
(0.04)\end{array}$ & $\begin{array}{c}0.29^{* * *} \\
(0.06)\end{array}$ & $\begin{array}{c}0.46^{* * *} \\
(0.06)\end{array}$ \\
\hline$R^{2}$ & 0.075 & 0.013 & 0.147 & 0.451 & 0.417 & 0.491 \\
\hline$F$-statistic & 150.17 & 11.59 & 169.51 & 37.16 & 9.26 & 29.84 \\
\hline Observations & 1875 & 876 & 999 & 1220 & 375 & 845 \\
\hline \multicolumn{7}{|c|}{$\begin{array}{l}\text { Notes: }{ }^{*} p<0.10,{ }^{* *} p<0.05,{ }^{* * *} p<0.01 \text {. Country-based cluster-robust standard errors in } \\
\text { parentheses. The dependent variable is the short-term interest rate regressed on the instrument, } \\
\text { fixed effects and when appropriate, controls. The set of controls includes: (i) the change in } \\
\text { short-term interest rate; (ii) the change in long-term interest rate; (iii) the change in mortgages } \\
\text { to GDP ratio; (iv) the change in real house prices as a ratio to per capita income; (v) real per } \\
\text { capita GDP growth; (vi) the change in the investment to GDP ratio; (vii) the change in the ratio of } \\
\text { non-mortgage loans to GDP ratio; (viii) CPI inflation; and (ix) the current account to GDP ratio. } \\
\text { We include contemporaneous terms and two lags. The full sample starts in } 1870 \text { and ends in } 2010 . \\
\text { The pre-WW2 sample ends in } 1938 \text {. The post-WW2 sample begins in 1946. World Wars omitted } \\
\text { from all samples. See text. }\end{array}$} \\
\hline
\end{tabular}

estimates). The pass-through of fluctuations in the instrument onto the short-term rate ranges as high as 0.8 (column 1) to 0.3 (column 2), which is economically sensible. Thus, the intuition from the scatter plots in Section 4 is well supported by the more formal analysis reported in the table.

\subsection{Estimates of the impulse responses}

Table 5 reports estimates of the LP-IV coefficients in expression (2) for each of the response variables (1)-(4) described in the previous section. The perturbation is to the short rate via the instrument, the responses reported are of the short and long rates, mortgage loans as a ratio to GDP and house prices over per capita income, all of them in percent. The table is organized as follows. For each response we report coefficient estimates of the LP-IV coefficient using all years except the two world wars. Below we check for robustness to different subsamples. In addition, we report summary regression statistics along with the Kleinbergen and Paap (2006) test of weak instruments.

In addition, Figure 8 contains four panels that display each of the four impulse responses reported in the table. The experiment depicted in these panels is a negative one percent decline in the short rate due to exogenous fluctuations in the instrument. We use this normalization so as to more closely characterize the recent experience of several 
Table 5: LP-IV: Estimation results based on full control set with the full sample

\begin{tabular}{|c|c|c|c|c|c|}
\hline Responses & Year $h=\mathrm{o}$ & Year $h=1$ & Year $h=2$ & Year $h=3$ & Year $h=4$ \\
\hline$\overline{\Delta_{h} \text { Short-term interest rate }}$ & 1.00 & $\begin{array}{c}1.31^{* * *} \\
(0.16)\end{array}$ & $\begin{array}{c}1.02^{* * *} \\
(0.19)\end{array}$ & $\begin{array}{c}\text { o.80*** } \\
(0.19)\end{array}$ & $\begin{array}{c}0.39^{* * *} \\
(0.14)\end{array}$ \\
\hline$R^{2}$ & & 0.474 & 0.303 & 0.278 & 0.261 \\
\hline Kleibergen-Paap & & 26.64 & 26.59 & 26.43 & 27.10 \\
\hline Observations & 1220 & 1201 & 1176 & 1152 & 1128 \\
\hline$\Delta_{h}$ Long-term interest rate & $\begin{array}{c}0.42^{* * *} \\
(0.05)\end{array}$ & $\begin{array}{c}0.55^{* * *} \\
(0.09)\end{array}$ & $\begin{array}{c}0.67^{* * *} \\
(0.13)\end{array}$ & $\begin{array}{c}0.60^{* * *} \\
(0.15)\end{array}$ & $\begin{array}{c}0.39^{* * *} \\
(0.13)\end{array}$ \\
\hline$R^{2}$ & 0.275 & 0.145 & 0.098 & 0.086 & 0.110 \\
\hline Kleibergen-Paap & $35 \cdot 58$ & 35.24 & 35.29 & 34.66 & 35.21 \\
\hline Observations & 1220 & 1200 & 1181 & 1163 & 1145 \\
\hline$\overline{\Delta_{h} \text { Mortgage Loans/GDP }}$ & $\begin{array}{c}-0.45^{* * *} \\
(0.15)\end{array}$ & $\begin{array}{c}-1.19^{* * *} \\
(0.38)\end{array}$ & $\begin{array}{c}-1.87^{* * *} \\
(0.61)\end{array}$ & $\begin{array}{c}-2.35^{* * *} \\
(0.76)\end{array}$ & $\begin{array}{c}-2.82^{* * *} \\
(0.86)\end{array}$ \\
\hline$R^{2}$ & 0.380 & 0.243 & 0.149 & 0.122 & 0.094 \\
\hline Kleibergen-Paap & 28.44 & 28.08 & $27 \cdot 90$ & $27 \cdot 97$ & 28.49 \\
\hline Observations & 1220 & 1197 & 1168 & 1139 & 1110 \\
\hline$\overline{\Delta_{h} \log (\text { House Price/Income) }}$ & $\begin{array}{l}-0.18 \\
(0.79)\end{array}$ & $\begin{array}{l}-1.76 \\
(1.67)\end{array}$ & $\begin{array}{l}-3.72^{*} \\
(2.05)\end{array}$ & $\begin{array}{l}-5.02^{* *} \\
(2.27)\end{array}$ & $\begin{array}{c}-4.37^{* *} \\
(1.88)\end{array}$ \\
\hline$R^{2}$ & 0.214 & 0.143 & 0.085 & 0.076 & 0.114 \\
\hline Kleibergen-Paap & 27.65 & 27.23 & 27.01 & 27.01 & $27 \cdot 53$ \\
\hline Observations & 1220 & 1202 & 1180 & 1158 & 1136 \\
\hline \multicolumn{6}{|c|}{$\begin{array}{l}\text { Notes: } \Delta_{h} \text { denotes change from year } t-1 \text { to } t+h .{ }^{*} p<0.10,{ }^{* *} p<0.05,{ }^{* * *} p<0.01 \text {. Country- } \\
\text { based cluster-robust standard errors in parentheses. Coefficient estimates of fixed effects and } \\
\text { controls not reported. The set of controls includes: (i) the change in short-term interest rate; (ii) } \\
\text { the change in long-term interest rate; (iii) the change in mortgages to GDP ratio; (iv) the change in } \\
\text { real house prices as a ratio to per capita income; (v) real per capita GDP growth; (vi) the change } \\
\text { in the investment to GDP ratio; (vii) the change in the ratio of non-mortgage loans to GDP ratio; } \\
\text { (viii) CPI inflation; and (ix) the current account to GDP ratio. We include contemporaneous terms } \\
\text { and two lags. The full sample starts in } 1870 \text { and ends in 2010. Kleibergen and Paap (2006) statistic } \\
\text { for weak instruments reported. World Wars omitted. See text. }\end{array}$} \\
\hline
\end{tabular}

countries in the periphery of the Eurozone and described in Section 3 . However, notice that the table reports the coefficient estimates directly from the regression output, which have the natural interpretation of a positive type of experiment instead. In other words, we flip the sign of the coefficient estimates from the table to construct the figure. We comment on the results for each variable, one at a time, starting with the response of the short rate to exogenous perturbations captured by the instrument. The results correspond to the first row block in Table 5 and panel (a) in Figure 8 . 
These results include country-specific cluster-robust standard errors. Clustering by country allows for fully flexible time series dependence in the errors within country blocks. Typical heteroscedasticy-and-autocorrelation (HAC) robust estimation procedures impose non-parametric, monotonically declining temporal dependence. If these conditions are met and if assumptions about the rate at which this dependence rate decays are also correct, a HAC estimator provides a more efficient approach to correct inference. Relying on clustering alone is more general than using a HAC estimator. However, cluster-robust standard errors tend to be more conservative. Rather than a flaw, we view this as an advantage. By showing that our estimates are significantly different from zero using correct (but more conservative) standard errors, we provide the reader an extra degree of insurance against spurious findings.

Year zero is the year when the shock is felt and the coefficient is therefore automatically normalized to one percent (for this reason we omit reporting standard errors and the $R^{2}$, which is equal to one). This will be the size of the perturbation with which to interpret subsequent responses. The effect of this perturbation is persistent and hump shaped. Years one thru three indicate that much of the effect on the short-term interest rate remains intact. Only in year four do we see the effect subsiding.

The persistence of the short rate response sets the stage for the analysis of the response of the long rate reported in the second row block of Table 5 and panel (b) of Figure 8 . The responses dampen relative to the short rate responses in a pattern entirely consistent with what is commonly found in the literature on term structure models (see, e.g., Evans and Marshall 1998). Recall that the response of the short-rate is somewhat persistent and this gets reflected in the persistent increase in the long rate, albeit with a pass through that is initially about one-half the initial perturbation to the short rate but growing over time.

The response of the long rate sets the stage for the analysis of the response of mortgage loans to GDP ratio. As we argued earlier, the long rate is a reasonable proxy for the mortgage rate and the responses reported in the third row block of Table 5 and panel (c) of Figure 8 bear this out. An exogenous one percent decrease/increase in the short rate results in about one-half percent decrease/increase in the long rate and on impact, on an increase/decrease in mortgage loans to GDP of about one half percent. However, the dynamic pattern indicates that the effect of the initial perturbation keeps building over time, and by year four there is about a three percent increase/decrease in mortgage loans as a ratio to GDP.

It would be natural to expect that, as the prices of mortgages decline/increase and hence mortgage loan activity increases/declines, house prices would correspondingly increase/decline. The fourth row block of Table 5 and panel (d) in Figure 8 show that this is indeed the case. The initial I percent perturbation to the short-rate translates to 
Figure 8: $L P-I V$ responses for an exogenous shock to the short-term interest rate

(a) Short-term interest rate

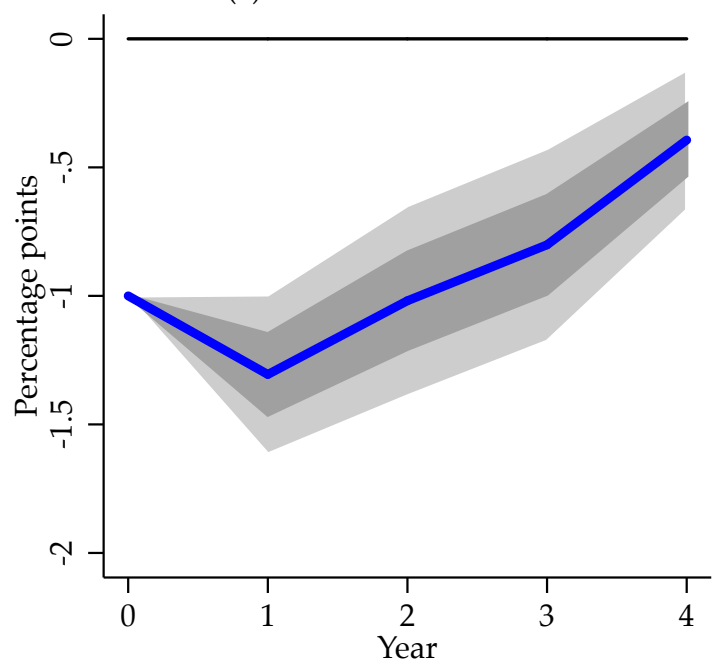

(c) Mortgage loans / GDP ratio

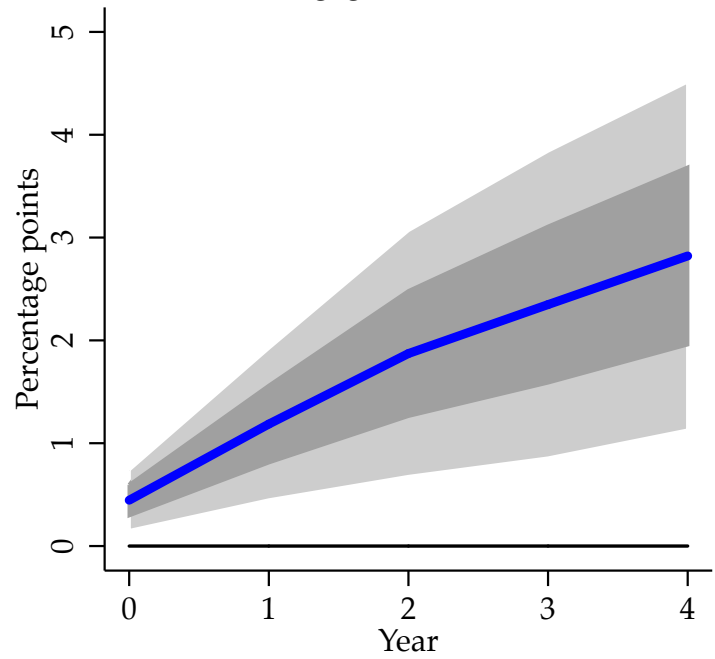

(b) Long-term interest rate

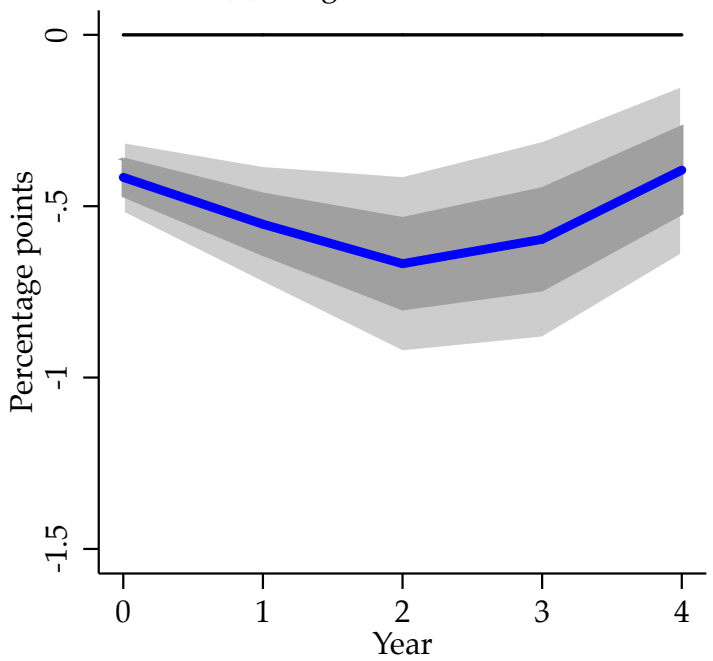

(d) $\log$ (House price/income ratio)

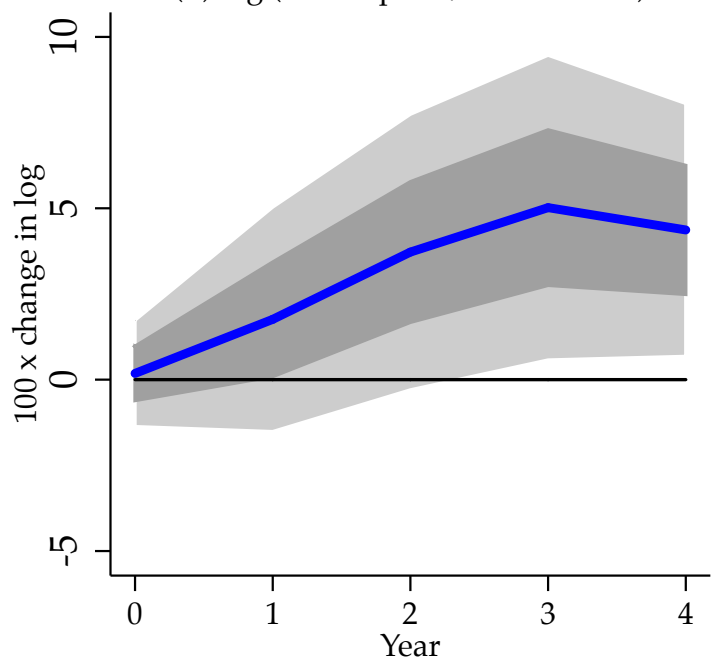

Notes: Each panel presents coefficient estimates from Table 5 for the full sample. Panel (a) is the response of the short term interest rate; panel (b) is the response of the long-term interest rate; panel (c) is the response of the ratio of mortgage lending to GDP; and panel (d) is the response of the ratio of house prices to income (per capita). Dark/light shaded areas are the 1 and 2 standard error confidence regions based on country-based cluster-robust standard errors. See text. 
about a 0.18 percent change in the house price to income ratio in Year o. Like in the case of mortgage lending, the effect of the initial perturbation keeps building over time. By year four the effect on the house price to income ratio is over 4 percent in magnitude.

Summarizing the results so far: a long historical view across developing economies allows us to use variation in exchange rate regimes over time and across countries to extract home fluctuations in short rates whose origin is dictated not by domestic conditions, but rather by conditions in the base country against whose currency the exchange rate is pegged. It is reasonable to suspect that pegs are endogenously determined. Even if they are not, there could still be considerable synchronicity of economic activity between the base and home countries. To purge for these effects, we include a rich set of controls that capture economic conditions in the home country.

The pairing of instrumental variables with saturated regression control is the best guarantee that the short rate perturbations we examine are exogenous given the data that we have. The analysis reveals that an exogenous decline in the short rate will result in a considerable increase in house prices. This decline does not appear to be spurious. The intermediate steps linking the short rate decline with a decline in the long rate and hence an increase in mortgage lending activity are all consistent with this result.

A potential concern, as with any panel data study, is that our historical dataset intertwines the experiences of countries with varied economic structures. Three responses should assuage such concerns. First, the sampling distribution of the impulse response estimates, itself a summary statistic of the heterogeneity in the data, indicates that our estimates have relatively contained dispersion. Second, using our historical dataset, GadeaRivas, Gómez-Loscos and Pérez-Quirós (2014) show that there is more heterogeneity across time than there is across countries. Third, one of the robustness checks we provide is a detailed subsample analysis that shows that our findings are very stable to using data from different historical eras.

Another potential concern, despite the many precautions that we adopt in the analysis, is that our results are driven by reverse causality. That is, could it be that a surge in the demand for housing explains the behavior of house prices mortgages and interest rates? We think that this mechanism can be easily ruled out. A surge in demand for housing would put simultaneous pressure on house prices and mortgages, which would translate into higher, not lower interest rates. For this reason, we feel reasonably confident that we have identified the correct channel linking a low interest rate environment with higher mortgage activity and house price appreciation. Our analysis provides a precise quantification of all these effects. In the next section we evaluate the robustness of these initial conclusions. 


\section{Robustness}

This section examines the reliability of the conclusions reached in the previous section to a variety of modifications in the analysis. We begin by exploring the benefits of the instrumental variable approach. Would the responses look much different had we estimated expression (2) by OLS? The answer turns out to be yes and we provide a comparison across methods to assess the extent of the attenuation bias that IV estimation alleviates. Next, some of the variables in the dataset do not extend quite as far and wide. This limitation results in a smaller sample available for estimation. Consequently, we re-estimate Table 5 but omit the controls so as to evaluate whether a larger sample could significantly change the results. As we will show, the estimates remain fairly stable considering that we omit an important set of controls. Finally, we consider the robustness of the analysis to different subsamples. Would the results still hold up if we focus on the pre- versus the post-WW2 eras? What about omitting the Bretton Woods era of fixed exchange rates? These and other alternatives are investigated below.

\subsection{OLS versus IV}

How useful is our instrumental variable? Table 6 provides a direct comparison of the IV estimates reported in Table 5 with estimates obtained using OLS in expression (2). For brevity, we do not report estimates of the country-fixed effects or the control set. We omit the general regression statistics and focus exclusively on the coefficient estimates and their standard errors. The table is organized into four row blocks, one for each of the response variables we have considered so far.

The general patterns of the responses are similar across methods but the coefficient estimates from OLS are greatly attenuated with respect to their IV counterparts. The OLS response of the short and long rates is between a third and one half the response calculated using IV. Not surprisingly, the response of mortgage lending is more muted, although here the degree of attenuation is much more noticeable. Nevertheless, these three responses are estimated fairly accurately and the broad contours of the analysis from the previous section would survive largely intact.

On the other hand, the response of house prices varies more noticeably. First, based on OLS the coefficient of the response during years zero and one are positive. This means that in response to a decline in the short rate (and a companion decline in the long rate and an increase in mortgage lending) house prices actually increase (albeit not significantly from the statistical point of view). Here the OLS bias not only attenuates the coefficient but it switches the sign and generates a response that is economically counterintuitive. 
Table 6: OLS v. IV: Comparing LP estimates using full control set, full sample

\begin{tabular}{|c|c|c|c|c|c|c|}
\hline$\overline{\text { Responses }}$ & & Year $h=0$ & Year $h=1$ & Year $h=2$ & Year $h=3$ & Year $h=4$ \\
\hline \multirow[t]{2}{*}{$\begin{array}{l}\Delta_{h} \text { Short-term } \\
\quad \text { interest rate }\end{array}$} & OLS & 1.00 & $\begin{array}{c}0.69^{* * *} \\
(0.06)\end{array}$ & $\begin{array}{c}0.45^{* * *} \\
(0.04)\end{array}$ & $\begin{array}{c}0.38^{* * *} \\
(0.05)\end{array}$ & $\begin{array}{c}0.35^{* * *} \\
(0.07)\end{array}$ \\
\hline & IV & 1.00 & $\begin{array}{l}1.31^{* * *} \\
(0.16)\end{array}$ & $\begin{array}{l}1.02^{* * *} \\
(0.19)\end{array}$ & $\begin{array}{l}0.8 \mathrm{o}^{* * *} \\
(0.19)\end{array}$ & $\begin{array}{c}0.39^{* * *} \\
(0.14)\end{array}$ \\
\hline \multirow[t]{2}{*}{$\begin{array}{l}\Delta_{h} \text { Long-term } \\
\text { interest rate }\end{array}$} & OLS & $\begin{array}{c}0.34^{* * *} \\
(0.03)\end{array}$ & $\begin{array}{c}0.33^{* * *} \\
(0.04)\end{array}$ & $\begin{array}{c}0.32^{* * *} \\
(0.04)\end{array}$ & $\begin{array}{c}0.26^{* * *} \\
(0.03)\end{array}$ & $\begin{array}{l}0.26^{* * *} \\
(0.03)\end{array}$ \\
\hline & & $\begin{array}{c}0.42^{* * *} \\
(0.05)\end{array}$ & $\begin{array}{c}0.55^{* * *} \\
(0.09)\end{array}$ & $\begin{array}{c}0.67^{* * *} \\
(0.13)\end{array}$ & $\begin{array}{c}0.60^{* * *} \\
(0.15)\end{array}$ & $\begin{array}{c}0.39^{* * *} \\
(0.13)\end{array}$ \\
\hline \multirow[t]{2}{*}{$\begin{array}{c}\Delta_{h} \text { Mortgage loans } \\
\text { /GDP }\end{array}$} & OLS & $\begin{array}{c}-0.11^{* * *} \\
(0.04)\end{array}$ & $\begin{array}{c}-0.15^{* *} \\
(0.06)\end{array}$ & $\begin{array}{c}-0.25^{* * *} \\
(0.08)\end{array}$ & $\begin{array}{c}-0.29^{* *} \\
(0.11)\end{array}$ & $\begin{array}{c}-0.45^{* * *} \\
(0.15)\end{array}$ \\
\hline & IV & $\begin{array}{c}-0.45^{* * *} \\
(0.15)\end{array}$ & $\begin{array}{c}-1.19^{* * *} \\
(0.38)\end{array}$ & $\begin{array}{c}-1.87^{* * *} \\
(0.61)\end{array}$ & $\begin{array}{c}-2.35^{* * *} \\
(0.76)\end{array}$ & $\begin{array}{c}-2.82^{* * *} \\
(0.86)\end{array}$ \\
\hline \multirow[t]{2}{*}{$\begin{array}{c}\Delta_{h} \log \text { House prices } \\
\text { /income }\end{array}$} & OLS & $\begin{array}{c}0.35 \\
(0.33)\end{array}$ & $\begin{array}{c}0.15 \\
(0.40)\end{array}$ & $\begin{array}{l}-0.33 \\
(0.48)\end{array}$ & $\begin{array}{l}-0.67 \\
(0.51)\end{array}$ & $\begin{array}{l}-0.90 \\
(0.56)\end{array}$ \\
\hline & IV & $\begin{array}{l}-0.18 \\
(0.79)\end{array}$ & $\begin{array}{l}-1.76 \\
(1.67)\end{array}$ & $\begin{array}{l}-3.72^{*} \\
(2.05)\end{array}$ & $\begin{array}{l}-5.02^{* *} \\
(2.27)\end{array}$ & $\begin{array}{l}-4 \cdot 37^{* *} \\
(1.88)\end{array}$ \\
\hline
\end{tabular}

Notes: $\Delta_{h}$ denotes change from year $t-1$ to $t+h .^{*} p<0.10,{ }^{* *} p<0.05,{ }^{* * *} p<0.01$. Countrybased cluster-robust standard errors in parentheses. Coefficient estimates of fixed effects and controls not reported. The set of controls includes: (i) the change in short-term interest rate; (ii) the change in long-term interest rate; (iii) the change in mortgages to GDP ratio; (iv) the change in real house prices as a ratio to per capita income; (v) real per capita GDP growth; (vi) the change in the investment to GDP ratio; (vii) the change in the ratio of non-mortgage loans to GDP ratio; (viii) CPI inflation; and (ix) the current account to GDP ratio. We include contemporaneous terms and two lags. World wars omitted. IV estimates from Table 5 repeated here for convenience. See text.

The signs are correct for years two to four although again, the coefficient estimates are considerably attenuated relative to their IV counterparts. Compare the $-0.90 \%$ year four response using OLS versus the $-4.37 \%$ response obtained with IV. We conclude from this analysis that our instrument is capturing movements in the short rate that are more likely to reflect exogenous fluctuations than fluctuations we could identify using a simple OLS regression control strategy.

\subsection{Responses when controls are excluded}

The identification strategy rests on two pillars: the instrumental variable and a rich set of controls to purge possible common base and home economic factors driving fluctuations in the instrument. In a classical instrumental variable setting, a truly exogenous instrument 
Table 7: LP-IV: Estimation results excluding control set, full sample

\begin{tabular}{|c|c|c|c|c|c|}
\hline Responses & Year $h=\mathrm{o}$ & Year $h=1$ & Year $h=2$ & Year $h=3$ & Year $h=4$ \\
\hline$\overline{\Delta_{h} \text { Short-term interest rate }}$ & 1.00 & $\begin{array}{c}1.34^{* * *} \\
(0.08)\end{array}$ & $\begin{array}{c}1.08^{* * *} \\
(0.09)\end{array}$ & $\begin{array}{c}0.91^{* * *} \\
(0.11)\end{array}$ & $\begin{array}{c}0.76^{* * *} \\
(0.13)\end{array}$ \\
\hline$R^{2}$ & & 0.557 & 0.346 & 0.280 & 0.242 \\
\hline Kleibergen-Paap & & 65.14 & 65.01 & $64 \cdot 50$ & 64.43 \\
\hline Observations & 1875 & 1852 & 1823 & 1795 & 1769 \\
\hline$\Delta_{h}$ Long-term interest rate & $\begin{array}{c}0.40^{* * *} \\
(0.05)\end{array}$ & $\begin{array}{c}0.55^{* * *} \\
(0.07)\end{array}$ & $\begin{array}{c}0.64^{* * *} \\
(0.10)\end{array}$ & $\begin{array}{c}0.61^{* * *} \\
(0.12)\end{array}$ & $\begin{array}{c}0.49^{* * *} \\
(0.11)\end{array}$ \\
\hline$R^{2}$ & -0.054 & -0.072 & -0.131 & -0.122 & -0.043 \\
\hline Kleibergen-Paap & 70.42 & 70.00 & 69.45 & 69.74 & 69.67 \\
\hline Observations & 1788 & 1764 & 1743 & 1723 & 1705 \\
\hline 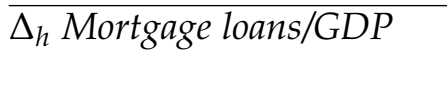 & $\begin{array}{c}-0.20^{* * *} \\
(0.07)\end{array}$ & $\begin{array}{c}-0.54^{* * *} \\
(0.18)\end{array}$ & $\begin{array}{c}-0.85^{* * *} \\
(0.31)\end{array}$ & $\begin{array}{c}-1.11^{* * *} \\
(0.39)\end{array}$ & $\begin{array}{c}-1.41^{* * *} \\
(0.49)\end{array}$ \\
\hline$R^{2}$ & 0.006 & -0.014 & -0.027 & -0.036 & -0.037 \\
\hline Kleibergen-Paap & $64 \cdot 50$ & 64.44 & 64.09 & 64.06 & 63.64 \\
\hline Observations & 1652 & 1627 & 1596 & 1564 & 1532 \\
\hline$\overline{\Delta_{h} \log \text { House prices/income }}$ & $\begin{array}{l}-0.06 \\
(0.52)\end{array}$ & $\begin{array}{l}-0.81 \\
(1.02)\end{array}$ & $\begin{array}{l}-2.00 \\
(1.26)\end{array}$ & $\begin{array}{c}-2.87^{* *} \\
(1.40)\end{array}$ & $\begin{array}{c}-2.96^{* *} \\
(1.22)\end{array}$ \\
\hline$R^{2}$ & -0.001 & -0.011 & -0.030 & -0.043 & -0.022 \\
\hline Kleibergen-Paap & 72.01 & 71.98 & 71.98 & 72.03 & 71.69 \\
\hline Observations & 1463 & 1444 & 1422 & 1400 & 1378 \\
\hline
\end{tabular}

would be sufficient to address bias induced by omitted controls. As a robustness check, we therefore reestimate the responses reported in Table 5 but omitting all controls except the country fixed effects. Omitting the controls results in a considerably larger sample, which also serves as an additional robustness check.

Table 7 replicates Table 5 but excludes the controls $\Delta W_{i t}$ and $\Delta X_{i t-1}$ from expression 2. The table is organized into four row blocks, just as Table 5 . The results reported in Table 7 are broadly comparable to those in Table 5 . The response of interest rates, both short- and long-term are in fact virtually indistinguishable. The response of mortgage lending is similar but more attenuated. Four years out the cumulative effect is -1.41 when controls are omitted versus -2.82 when controls are included. Similarly, the response of house prices at year four is -2.96 when controls are excluded, versus -4.37 when controls 
are included. Another way to interpret these results is in the context of the OLS versus IV comparison of Table 6. The attenuation bias we described in the previous section is largely resolved by using IV estimation.

\subsection{Robustness to sample choices}

The final set of robustness checks explores different ways to partition the sample and to construct the instrument. We consider five alternative scenarios. The analysis in Section 2 suggests that the share of total lending dedicated to mortgage lending began its ascent at the end of World War 2. A natural exercise is to examine the sensitivity of our results to partitioning the sample before and after World War 2. Call them scenarios (1) and (2). Next, we assess the sensitivity of the results to our construction of the instrument. We do this in two ways: by treating the Bretton Woods era as non-instrumented; and more drastically, by excluding this period entirely from the sample. Call these scenarios (3) and (4). Finally, the interwar period is particularly volatile (it includes the Great Depression). As a final check, we re-estimate the responses using a sample that excludes the period 1914to 1972, that is, also excluding the Bretton Woods era. Call this scenario (5). In order to economize space, we report only the coefficients of each response in year four along with summary regression statistics.

Table 8 replicates baseline results from the full sample in year 4 from Table 5 . These results are reported in column (o), which serves as a benchmark for each of the five scenarios just described and reported in columns (1)-(5). Several results deserve comment. Except for the pre-WW2 results reported in column (1), the stability of our findings across experiments is quite notable. The response of the short and long rates vary over a very narrow range of about 0.1 to 0.15 percentage points. The variation in the responses to mortgage lending and house prices is a little wider, but so are the responses themselves. In the case of mortgage lending, the response varies from -2.67 to -3.47 and in the case of house prices it can vary from -4.37 to -5.88 . These ranges of variation are in any case quite a bit smaller than the $95 \%$ confidence intervals implied by estimates themselves. Pre-WW2 responses are more volatile, in part because the sample has more gaps, in part because it contains the more volatile interwar period (which includes the Great Depression), and in part because the role of mortgage lending (and the behavior of credit more generally) changed around the end of World War 2. Nevertheless, even the results in column (1) do not stray far from the results in column (o) or those in columns (2)-(5), which is reassuring. 
Table 8: LP-IV: Estimation results including control set, robustness checks, year-4 response only

\begin{tabular}{|c|c|c|c|c|c|c|}
\hline Responses in year 4 & $\begin{array}{c}\text { (o) } \\
\text { All } \\
\text { Years }\end{array}$ & $\begin{array}{c}(1) \\
\text { Pre- } \\
W W 2\end{array}$ & $\begin{array}{c}(2) \\
\text { Post- } \\
\text { WW2 }\end{array}$ & $\begin{array}{c}(3) \\
\text { Set } z=0 \\
1946-72\end{array}$ & $\begin{array}{c}(4) \\
\text { Exclude } \\
1946-72\end{array}$ & $\begin{array}{c}\quad(5) \\
\text { Exclude } \\
1914-72\end{array}$ \\
\hline$\Delta_{4}$ Short-term interest rate & $\begin{array}{c}0.39^{* * *} \\
(0.14)\end{array}$ & $\begin{array}{l}0.36^{* *} \\
(0.18)\end{array}$ & $\begin{array}{l}0.31^{*} \\
(0.18)\end{array}$ & $\begin{array}{l}0.36^{* *} \\
(0.16)\end{array}$ & $\begin{array}{l}0.39^{* *} \\
(0.16)\end{array}$ & $\begin{array}{c}0.30 \\
(0.23)\end{array}$ \\
\hline$R^{2}$ & 0.261 & 0.344 & 0.312 & 0.261 & 0.266 & 0.287 \\
\hline Kleibergen-Paap & 27.10 & 9.67 & 26.59 & 27.84 & 25.07 & 21.16 \\
\hline Observations & 1128 & 347 & 781 & 1128 & 917 & 761 \\
\hline$\overline{\Delta_{4}}$ Long-term interest rate & $\begin{array}{c}0.39^{* * *} \\
(0.13)\end{array}$ & $\begin{array}{c}0.40^{* * *} \\
(0.15)\end{array}$ & $\begin{array}{c}0.24 \\
(0.15)\end{array}$ & $\begin{array}{c}0.40^{* * *} \\
(0.14)\end{array}$ & $\begin{array}{c}0.41^{* * *} \\
(0.14)\end{array}$ & $\begin{array}{l}0.36^{*} \\
(0.18)\end{array}$ \\
\hline$R^{2}$ & 0.110 & 0.312 & 0.177 & 0.110 & 0.113 & 0.125 \\
\hline Kleibergen-Paap & 35.21 & 8.89 & 33.23 & 34.07 & 32.21 & 25.27 \\
\hline Observations & 1145 & 368 & 777 & 1145 & 938 & 779 \\
\hline$\overline{\Delta_{4}}$ Mortgage loans/GDP & $\begin{array}{c}-2.82^{* * *} \\
(0.86)\end{array}$ & $\begin{array}{l}-1.94 \\
(1.32)\end{array}$ & $\begin{array}{c}-2.67^{* * *} \\
(0.91)\end{array}$ & $\begin{array}{c}-2.95^{* * *} \\
(0.95)\end{array}$ & $\begin{array}{c}-3.10^{* * *} \\
(0.93)\end{array}$ & $\begin{array}{c}-3.47^{* * *} \\
(1.06)\end{array}$ \\
\hline$R^{2}$ & 0.094 & 0.173 & 0.108 & 0.076 & 0.103 & 0.021 \\
\hline Kleibergen-Paap & 28.49 & $9 \cdot 49$ & 28.29 & $29 \cdot 48$ & 26.52 & 22.84 \\
\hline Observations & 1110 & 329 & 781 & 1110 & 899 & 768 \\
\hline $\bar{\Delta}_{4} \log$ House prices/income & $\begin{array}{c}-4 \cdot 37^{* *} \\
(1.88)\end{array}$ & $\begin{array}{l}-1.34 \\
(4.82)\end{array}$ & $\begin{array}{c}-5 \cdot 37^{* *} \\
(2.12)\end{array}$ & $\begin{array}{c}-4.66^{* *} \\
(2.14)\end{array}$ & $\begin{array}{c}-4 \cdot 38^{* *} \\
(2.04)\end{array}$ & $\begin{array}{c}-5.88^{* * *} \\
(2.25)\end{array}$ \\
\hline$R^{2}$ & 0.114 & 0.197 & 0.202 & 0.108 & 0.112 & 0.085 \\
\hline Kleibergen-Paap & $27 \cdot 53$ & 7.99 & 24.99 & 27.92 & 25.25 & 20.01 \\
\hline Observations & 1136 & 355 & 781 & 1136 & 925 & 780 \\
\hline
\end{tabular}

Notes: $\Delta_{h}$ denotes change from year $t-1$ to $t+h .^{*} p<0.10,{ }^{* *} p<0.05,{ }^{* * *} p<0.01$. Countrybased cluster-robust standard errors in parentheses. Coefficient estimates of fixed effects and controls omitted. The set of controls includes: (i) the change in short-term interest rate; (ii) the change in long-term interest rate; (iii) the change in mortgages to GDP ratio; (iv) the change in real house prices as a ratio to per capita income; (v) real per capita GDP growth; (vi) the change in the investment to GDP ratio; (vii) the change in the ratio of non-mortgage loans to GDP ratio; (viii) CPI inflation; and (ix) the current account to GDP ratio. The table reports full sample estimation results in column (o) to serve as a benchmark. Column (1) refers to results based on a pre-WW2 sample. Column (2) uses a post-WW2 sample instead. Column (3) treats the Bretton Woods area as a period for which the instrument does not apply. Column (4) excludes the Bretton Woods era altogether from the sample. Column (6) excludes the interwar the Bretton Woods period from the sample. We include contemporaneous terms and two lags. K-P refers to the Kleibergen and Paap (2006) statistic for weak instruments reported. world wars omitted. See text. 


\section{MORTGAge LENDING, HOUSE PRICES AND FINANCIAL CRISES}

Section 6 showed that loose monetary conditions make credit cheaper, purchasing a home easier, and therefore houses more expensive. One of the narratives of the recent global financial crisis puts at its center a similar mechanism, see e.g. Mian and Sufi (2010, 2014).

Yet alternative narratives for the global financial crisis have emerged too. Some emphasize the role of excessive sovereign debt (e.g., Reinhart and Rogoff 2010, 2012), and others the interplay between private and public debt (e.g., Jordà, Schularick and Taylor 2013b). Fears that the sovereigns will be unable to absorb losses in the banking sector can put into question the solvency of the sovereign itself. This fear quickly spreads to banks with substantial holdings of public debt, setting in motion what some call a "diabolical loop" (e.g., Brunnermeier et al. 2011). Jordà, Schularick and Taylor (2013b) found that crises are driven primarily by private credit rather than public debt, although their aftermath is certainly influenced by the level of public debt existing at their inception.

When it comes to financial crises, a growing consensus emphasizes the role of excessive private debt (see, e.g., Borio and White 2004; Schularick and Taylor 2012; Gourinchas and Obstfeld 2012; Jordà, Schularick and Taylor 2013a). Moreover, some recent research has focused attention on the role played households' mortgage debt (Mian and Sufi 2010, 2014; Büyükkarabacak and Valev 2010), and in this paper we expand on these ideas by looking at the interaction between booms in housing debt that coincide with house price bubbles using the new long-run data introduced earlier.

This section explores these questions in historical perspective. Because financial crises are rare, we reach back in history and across a wide cross section of developed economies to examine the role that mortgage lending and house prices have exerted on the likelihood of experiencing a financial crisis. The chronology of financial crises relies on the dates available in Jordà, Schularick and Taylor (2013a) and the sources cited therein.

The dependent variable is binary and takes the value of 1 if for a given country-year pair there is a financial crisis, and it is zero otherwise. The two explanatory variables that we consider, mortgage lending as a ratio to GDP and house prices as a ratio to per capita income, enter as five year moving averages to parsimoniously capture conditions in the lead up to the crisis. In addition we include country fixed effects. On average, some countries have been more prone to financial crises than others and the fixed effects account for these differences. Our goal is not to thoroughly examine every possible factor and specification that may determine when a financial crisis will happen. Rather we simply want to document the link between housing finance and financial crises.

Methodologically, we rely on classification methods rather than evaluating model fit. We are interested in evaluating the ability to sort into crisis versus no crisis events 
rather than in evaluating whether the conditional probability of a crisis is appropriately characterized by the model. The emphasis is on the informational content of the controls, not on the correct specification of the model. In other words, we are interested in knowing whether tomorrow will rain or not (a crisis will happen or not) in order to decide whether to carry an umbrella or not (take policy action that is costly but may prevent the crisis). We rely on a well-established literature in biostatistics and machine learning to provide suitable answers.

We approach the problem in two simple steps. First we fit a logit model of the crisis dependent variable using the mortgage and house price moving average controls as well as fixed effects. The model specification only acts as a tool to find suitable linear combinations of the controls whose informational content we then evaluate. Using predictions from this model, we then calculate true positive and true negative rates as follows. Consider the rule that calls a crisis whenever the predicted conditional probability from the logit exceeds a threshold $c \in[0,1]$. This threshold need not be 0.5 , in fact, it is allowed to vary. The true positive rate is the proportion of correctly called crises associated with any $c$ and the true negative rate is the proportion of correctly called non-crises instead. Choose a c close to $I$ and the true negative rate approaches $I$ but the true positive rate deteriorates. The opposite happens when $c$ tends to zero. Given a classification technology, one can allocate information to predict one outcome or the other in different proportions depending on where the emphasis is needed.

The map of the true positive and true negative rates for each $c \in[0,1]$ is a curve that Jordà and Taylor (2011) denote the correct classification frontier (CCF) in reference to the classic economic concept of a production possibilities frontier. The better the classification technology, the further is this curve from the origin. A perfect classifier is one whose CCF is the unit square. By contrast, a classifier that is no better than random chance has a CCF equivalent to the diagonal bisecting the unit square. The area under the CCF is a measure of the model's classification ability and is equivalent to the area under the receiver operating characteristic (ROC) curve or AUC, used frequently in biostatistics to evaluate medical tests (see, e.g. Pepe 2003 for a survey). The AUC for an uninformative classifier is readily seen to be equal to 0.5 (half the area of the unit square) whereas for the perfect classifier on the unit square it is 1 . The AUC turns out to have an asymptotic Gaussian distribution, which makes this statistic convenient for hypothesis testing.

Table 9 summarizes the main results of this exercise for the full sample, and for robustness, the pre- and post-WW2 samples. The table is organized as follows. The top row-block shows the coefficient estimates whereas the bottom row-block provides each model's AUC and a test of the null hypothesis that the AUC from the model is statistically equivalent to a benchmark AUC. The benchmark AUC is constructed using a model with 
Table 9: Classifying financial crises using mortgage lending and house prices. Logit models and AUC statistics for correct classification frontiers, full, pre-WW2, and post-WW2 samples

\begin{tabular}{|c|c|c|c|}
\hline (a) Logit models, country fixed effects & $\begin{array}{c}(1) \\
\text { All years }\end{array}$ & $\begin{array}{c}(2) \\
\text { Pre-WW2 }\end{array}$ & $\begin{array}{c}(3) \\
\text { Post-WW2 }\end{array}$ \\
\hline $\begin{array}{l}\text { Mortgage loans/GDP, } \\
\text { lagged 5-year change }\end{array}$ & $\begin{array}{c}0.14 \\
(0.10)\end{array}$ & $\begin{array}{c}0.00 \\
(0.15)\end{array}$ & $\begin{array}{l}0.25^{*} \\
(0.13)\end{array}$ \\
\hline $\begin{array}{l}\log \text { (House prices/income) } \\
\text { lagged 5-year change }\end{array}$ & $\begin{array}{l}0.09^{* *} \\
(0.04)\end{array}$ & $\begin{array}{l}0.10^{*} \\
(0.06)\end{array}$ & $\begin{array}{l}0.09^{*} \\
(0.05)\end{array}$ \\
\hline Observations & 1323 & 439 & 848 \\
\hline \multicolumn{4}{|l|}{ (b) Correct classification frontier statistics } \\
\hline Model AUC & $\begin{array}{c}0.67 \\
(0.04)\end{array}$ & $\begin{array}{c}0.67 \\
(0.06)\end{array}$ & $\begin{array}{c}0.71 \\
(0.06)\end{array}$ \\
\hline Benchmark AUC, country fixed effects only & $\begin{array}{c}0.56 \\
(0.04)\end{array}$ & $\begin{array}{c}0.57 \\
(0.05)\end{array}$ & $\begin{array}{c}0.62 \\
(0.05)\end{array}$ \\
\hline$H_{0}:$ AUC model = AUC benchmark ( $\mathrm{p}$-value) & 0.01 & 0.10 & 0.05 \\
\hline
\end{tabular}

Notes: ${ }^{*} p<0.10,{ }^{* *} p<0.05,{ }^{* * *} p<0.01$. Dependent variable takes the value of 1 when there is a crisis for a given country-year, o otherwise. Panel (a) reports logit coefficients and standard errors in parentheses. Correct classification frontier for column (1) shown in Figure 9 In panel (b) AUC benchmark refers to the AUC for a null logit model with country fixed effects only, but no other controls. AUC model refers to the AUC for the logit model whose coefficients we report. World Wars omitted. See text.

fixed effects but no covariates. In addition Figure 9 displays the CCF curve associated with the full sample results to provide a visual comparison of the CCF for the models with and without covariates.

The broad picture painted by these results is that mortgage lending and house prices have information about the likelihood of a financial crisis but that this information is clearly insufficient to generate a perfect prediction of financial crises. The numerical values of the coefficient estimates reported in the top row block of Table 9 are themselves of little interest. They are reported to illustrate the relative significance of the controls in the full sample specification. Loadings for the pre-WW2 sample are similar as those in the full sample although in the post-WW2 the loadings appear to be both on mortgage lending and house prices.

Nevertheless, there is non-negligible information in these covariates. The null benchmark AUC, from a model with fixed effects but no other covariates, is only 0.56. This is not significantly different from the reference AUC of 0.5 for a completely uninformative classifier. The interpretation is that, although there are differences in the rate of crises 
Figure 9: Classifying financial crises using mortgage lending and house prices

Correct classification frontiers (CCF), full sample 1870-2008, all countries

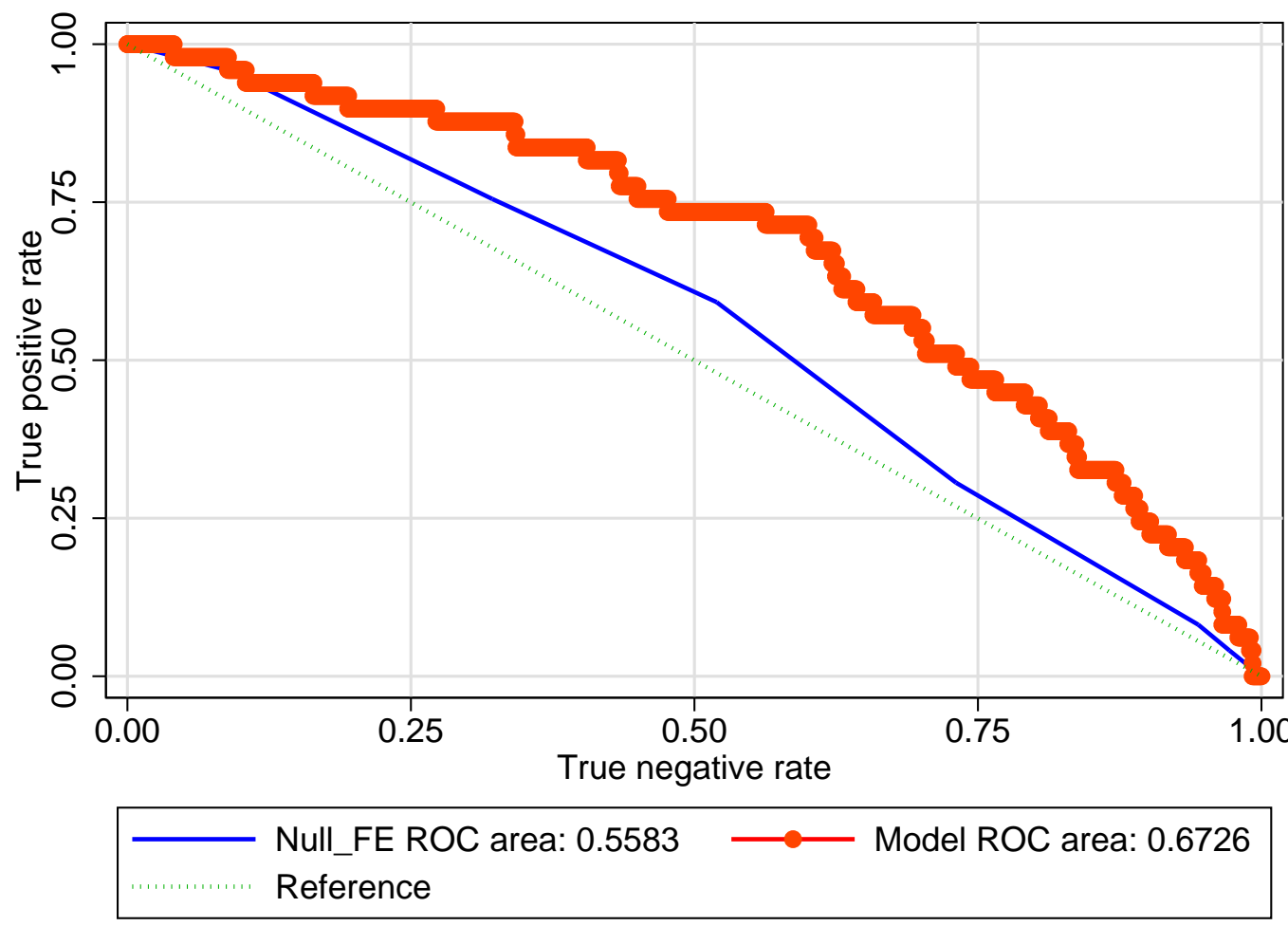

Notes: Null benchmark CCF using country fixed effects only is solid blue line with AUC $=0.53$. Model CCF is red line with large circles with AUC $=0.66$ and corresponds to model (1) from Table 9 . Standard errors in parentheses. Reference uninformative classifier CCF is dotted green line with $\mathrm{AUC}=0.5$. See text.

experienced across countries, these differences are small. AUCs from the benchmark model range from a low of 0.67 in the full and pre-WW2 samples, to a high of 0.71 for the post-WW2 sample, which is statistically different from the benchmark. As a complement, Figure 9 displays the correct classification frontier for the full sample estimates, which forms the basis for the AUC calculations reported in the table.

What is the takeaway? Our historical analysis at business-cycle frequency outlines how accommodative monetary conditions can be accompanied by more mortgage lending and higher house prices. Both of these variables have been touted as possible factors in a financial crisis and our historical analysis using crisis prediction models suggests that there is some truth to this view. Moreover, we once more find evidence that these effects have become stronger with the rapid rise of real estate lending in the second half of the 2oth century. 


\section{Conclusion}

The global financial crisis brought to the fore trends in housing markets that had been brewing over the decades following WW2, a break from the relative stability of the preWW2 era. A mixture of financial liberalization, government support, risk taking by banks, and levering up by households brought about greater rates of home ownership across the developed world. Disentangling the importance of these various forces, which surely varied by time and place, is a difficult goal for future research, and is beyond the scope of this paper. Yet the rise of leveraged real estate booms has been identified by much recent research as being central to the understanding of financial crises. After presenting this historical evidence, this paper makes two key contributions to the understanding of the link between monetary conditions, mortgage credit and house prices.

We use fluctuations in monetary conditions that have their origin in macroeconomic conditions elsewhere as a natural experiment. Such fluctuations serve as instrumental variables to trace dynamic responses of mortgage lending and house prices. At business cycle frequencies, we find robust evidence in support of a direct mechanism linking shortterm rates, mortgage lending and house prices. Through the term structure, long-term rates respond to short-term rates, thus affecting the price of mortgages. In response to easing monetary conditions and hence a decline in the price of mortgages, mortgage lending expands. Rising house prices improve the value of the mortgage's collateral, and with it a bank's asset position and its ability to lend further. Loose monetary conditions are causal for mortgage and house price booms, and this effect has become much more dramatic since WW2.

It is natural to suspect that such a feedback loop could set in motion conditions for a housing boom and increased leverage, which in turn heightens the risk of a financial crash down the road. The long run view from economic history suggests that such mechanisms are a regular feature of the modern financial cycle, and we use statistical methods from the literature on binary classifiers to explore this question. Using logit models, the correct classification frontier, and tests based on the area under the curve, we find that over a 5 -year window run ups in mortgage lending and run ups in house prices raise the likelihood of a subsequent financial crises. Mortgage and house price booms are predictive of future financial crises, and this effect has also become much more dramatic since WW2.

What are the implications of these findings for the ongoing debate about monetary policy in the post-crisis age? How much should central banks worry about the financial stability risks of loose monetary conditions? Our findings suggests the side-effects of easy low interest rates should be cause for some concern. Real estate lending has grown strongly during the 2oth century and now accounts for the dominant share of bank 
lending in many countries; the sensitivity of mortgage lending and house prices to changes in monetary conditions has also increased substantially. A key implication of this result is that central banks cannot pursue macroeconomic stabilization policy without being mindful of the consequences for credit markets and financial stability. However, none of this should be taken to imply that that tighter monetary conditions are the right answer. The findings from our study call for a nuanced approach. Central banks should acknowledge that the trade-offs they face can potentially be managed through greater use of macro-prudential tools. Macroeconomic history refutes the notion that the joint objectives of macroeconomic stabilization and financial stability can be examined in isolation.

\section{REFERENCES}

Adam, Klaus, and Michael Woodford. 2013. Housing Prices and Robustly Optimal Monetary Policy. University of Mannheim. Photocopy.

Ahamed, Liaquat. 2009. Lords of Finance: The Bankers Who Broke the World. New York: Penguin.

Aizenman, Joshua, Menzie D. Chinn, and Hiro Ito. 2008. Assessing the Emerging Global Financial Architecture: Measuring the Trilemma's Configurations over Time. NBER Working Paper 14533.

Allen, Franklin, Thorsten Beck, Elena Carletti, Philip Lane, Dirk Schoenmaker, and Wolf Wagner. 2011. Cross-Border Banking in Europe: Implications for Financial Stability and Macroeconomic Policies. London: CEPR.

Allen, Franklin, and Kenneth Rogoff. 2011. Asset Prices, Financial Stability and Monetary Policy. The Wharton School of the University of Pennsylvania. Financial Institutions Center. In Sveriges Riksbank, The Riksbank's Inquiry into the Risks in the Swedish Housing Market. Stockholm: Sveriges Riksbank, pp. 189-217.

Bernanke, Ben S. 2010. Monetary Policy and the Housing Bubble. Speech at the Annual Meeting of the American Economic Association, Atlanta, Georgia. http://www.federalreserve. gov/newsevents/speech/bernanke20100103a.

Bonnet, Odran, Pierre-Henri Bono, Guillaume Chapelle, and Etienne Wasmer. 2014. Does Housing Capital Contribute to Inequality? SciencesPo Discussion Paper 2014-07.

Bordo, Michael D., and John Landon-Lane. 2013. What Explains House Price Booms? History and Empirical Evidence. NBER Working Papers 19584.

Borio, Claudio, and William R. White. 2004. Whither Monetary and Financial Stability? The Implications of Evolving Policy Regimes. In Monetary Policy and Uncertainty: Adapting to a Changing Economy. Proceedings of the 2003 Jackson Hole Economic Policy Symposium, Jackson Hole, Wyo., 28-30 August, pp. 131-211.

Brunnermeier, Markus K., Luis Garicano, Philip R. Lane, Marco Pagano, Ricardo Reis, Tano Santos, David Thesmar, Stijn Van Nieuwerburgh and Dimitri Vayanos. 2011. European Safe Bonds (ESBies). Columbia University, mimeograph. 
Buiter, Willem H., Giancarlo M. Corsetti, and Paolo A. Pesenti. 1998. Interpreting the ERM Crisis: Country-Specific and Systemic Issues. Princeton Studies in International Finance 84 .

Büyükkarabacak, Berrak, and Neven T. Valev. 2010. The Role of Household and Business Credit in Banking Crises. Journal of Banking \& Finance 34(6): 1247-56.

Del Negro, Marco, and Christopher Otrok. 2007. 99 Luftballons: Monetary Policy and the House Price Boom Across U.S. States. Journal of Monetary Economics 54(7): 1962-85.

di Giovanni, Julian, and Jay C. Shambaugh. 2008. The Impact of Foreign Interest Rates on the Economy: The Role of the Exchange Rate Regime. Journal of International Economics 74(2): 341-61.

Eichengreen, Barry. 1992. Golden Fetters: The Gold Standard and the Great Depression. New York: Oxford University Press.

Evans, Charles L. and David A. Marshall. 1998. Monetary Policy and the Term Structure of Nominal Interest Rates: Evidence and Theory. Carnegie-Rochester Conference Series on Public Policy, 49: 53-111.

Gadea-Rivas, Maria Dolores, Ana Gómez-Loscos and Gabriel Pérez-Quirós. 2014. The Two Greatest. Great Recession vs. Great Moderation. CEPR working paper DP1oog2.

Glaeser, Edward, Joshua Gottlieb and Joseph Gyourko. 2010. Can Cheap Credit Explain the Housing Boom? NBER Working Paper 16239.

Goodhart, Charles, and Boris Hofmann. 2008. House prices, money, credit, and the macroeconomy. Oxford Review of Economic Policy 24(1): 180-205.

Gourinchas, Pierre-Olivier, and Maurice Obstfeld. 2012. Stories of the Twentieth Century for the Twenty-First. American Economic Journal: Macroeconomics. 4(1): 226-65.

Ilzetzki, Ethan, Enrique G. Mendoza, and Carlos A. Végh. 2013. How Big (Small?) are Fiscal Multipliers? Journal of Monetary Economics 6o(2): 239-254.

Ilzetzki, Ethan, Carmen Reinhart, and Kenneth Rogoff. 2008. Exchange Rate Arrangements Entering the 21st Century: Which Anchor Will Hold? University of Maryland and Harvard University. Unpublished.

Irwin, Douglas A. 2010. Did France Cause the Great Depression? NBER Working Paper 16350.

Jarocinski, Marek, and Frank Smets. 2008. House Prices and the Stance of Monetary Policy. Federal Reserve Bank of St. Louis Review 90(4): 339-65.

Jordà, Oscar. 2005. Estimation and Inference of Impulse Responses by Local Projections. American Economic Review, 95(1): 161-182.

Jordà, Òscar, Moritz Schularick, and Alan M. Taylor. 2013. When Credit Bites Back. Journal of Money, Credit and Banking 45(S2): 3-28.

Jordà, Òscar, Moritz Schularick, and Alan M. Taylor. 2014. The Great Mortgaging. Unpublished.

Jordà, Òscar, and Alan M. Taylor. 2011. Performance Evaluation of Zero Net-Investment Strategies. NBER Working Paper 17150.

Kenen, Peter. 1969. The Theory of Optimum Currency Areas: An Eclectic View. In Monetary Problems in the International Economy edited by Robert A. Mundell and Alexander K. Swoboda. Chicago: University of Chicago Press, pp. 41-6o. 
Kleibergen, Frank and Richard Paap. 2006. Generalized reduced rank tests using the singular value decomposition. Journal of Econometrics, 133(1): 97-126.

Klein, Michael, and Jay Shambaugh. 2013. Rounding the Corners of the Policy Trilemma: Sources of Monetary Policy Autonomy. NBER Working Paper 19461.

Knoll, Katharina. 2012. White Picket Finance: The Making of the U.S. Mortgage Market, 1932-1960. In Public Policies and the Direction of Financial Flows, edited by Hubert Bonin, Alfredo Gigliobianco, Niels-Viggo Haueter, and Harold James. Bucharest: European Association for Banking and Financial History and National Bank of Romania.

Knoll, Katharina, Moritz Schularick, and Thomas Steger. 2014. No Price Like Home: Global House Prices, 1870-2012. Draft manuscript. Free University of Berlin.

Kuttner, Kenneth. 2012. Low Interest Rates and Housing Bubbles: Still No Smoking Gun. Williams College, Department of Economics Working Papers 2012-01.

Lane, Philip R. 2012. The European Sovereign Debt Crisis. Journal of Economic Perspectives 26(3): 49-68.

Leamer, Eric E. 2007. Housing is the Business Cycle. National Bureau of Economic Research working paper 13428.

Leduc, Sylvain and Daniel Wilson. 2013. Are State Government Roadblocks to Federal Stimulus? Evidence from Highway Grants in the 2009 Recovery Act. Federal Reserve Bank of San Francisco, Working Paper 2013-16.

Malkin, Israel, and Fernanda Nechio. 2012. U.S. and Euro-Area Monetary Policy by Regions. Federal Reserve Bank of San Francisco, FRBSF Economic Letter. February 27. Mian, Atif, and Amir Sufi. 2014. House of Debt. Chicago: University of Chicago Press.

Mian, Atif, and Amir Sufi. 2010. Household Leverage and the Recession of 2007-09. IMF Economic Review 58(1): 74-117.

Mundell, Robert A. 1961. A Theory of Optimum Currency Areas. American Economic Review 51(4): 657-65.

Obstfeld, Maurice, Jay C. Shambaugh, and Alan M. Taylor. 2004 Monetary Sovereignty, Exchange Rates, and Capital Controls: The Trilemma in the Interwar Period. IMF Staff Papers 51(S): 75-108.

Obstfeld, Maurice, Jay C. Shambaugh, and Alan M. Taylor. 2005. The Trilemma in History: Tradeoffs among Exchange Rates, Monetary Policies, and Capital Mobility. Review of Economics and Statistics 87 (August 2005): 423-38.

Obstfeld, Maurice, and Alan M. Taylor. 2004. Global Capital Markets: Integration, Crisis, and Growth. New York: Cambridge University Press.

O'Rourke, Kevin H., and Alan M. Taylor. 2013. Cross of Euros. Journal of Economic Perspectives 27(3): 167-92.

Owyang, Michael T., Valerie A. Ramey and Sarah Zubairy. 2013. Are Government Spending Multipliers Greater during Periods of Slack? Evidence from Twentieth Century Historical Data. American Economic Review, 103(3): 129-34.

Pepe, Margaret S. 2003. The Statistical Evaluation of Medical Tests for Classification and Prediction. Oxford: Oxford University Press.

Quinn, Dennis P., Martin Schindler, and A. Maria Toyoda. 2011. Assessing Measures of Financial Openness and Integration. IMF Economic Review 59(3): 488-522. 
Reinhart, Carmen M., and Vincent Reinhart. 2011. Pride Goes Before a Fall: Federal Reserve Policy and Asset Markets. NBER Working Paper 16815.

Reinhart, Carmen M., and Kenneth S. Rogoff. 2009. This Time is Different: Eight Centuries of Financial Folly. Princeton, N.J.: Princeton University Press.

Schularick, Moritz, and Alan M. Taylor. 2012. Credit Booms Gone Bust: Monetary Policy, Leverage Cycles, and Financial Crises, 1870-2008. American Economic Review 102(2): 1029-61.

Taylor, John. B. 2007. Housing and Monetary Policy. NBER Working Paper 13682.

Williams, John. C. 2011. Monetary Policy and Housing Booms. International Journal of Central Banking 7(1): 345-55. 